\title{
REVIEW ARTICLE OPEN Addiction is driven by excessive goal-directed drug choice under negative affect: translational critique of habit and compulsion theory
}

Lee Hogarth (iD) ${ }^{1}$

Drug addiction may be a goal-directed choice driven by excessive drug value in negative affective states, a habit driven by strong stimulus-response associations, or a compulsion driven by insensitivity to costs imposed on drug seeking. Laboratory animal and human evidence for these three theories is evaluated. Excessive goal theory is supported by dependence severity being associated with greater drug choice/economic demand. Drug choice is demonstrably goal-directed (driven by the expected value of the drug) and can be augmented by stress/negative mood induction and withdrawal-effects amplified in those with psychiatric symptoms and drug use coping motives. Furthermore, psychiatric symptoms confer risk of dependence, and coping motives mediate this risk. Habit theory of addiction has weaker support. Habitual behaviour seen in drug-exposed animals often does not occur in complex decision scenarios, or where responding is rewarded, so habit is unlikely to explain most human addictive behaviour where these conditions apply. Furthermore, most human studies have not found greater propensity to habitual behaviour in drug users or as a function of dependence severity, and the minority that have can be explained by task disengagement producing impaired explicit contingency knowledge. Compulsion theory of addiction also has weak support. The persistence of punished drug seeking in animals is better explained by greater drug value (evinced by the association with economic demand) than by insensitivity to costs. Furthermore, human studies have provided weak evidence that propensity to discount cost imposed on drug seeking is associated with dependence severity. These data suggest that human addiction is primarily driven by excessive goal-directed drug choice under negative affect, and less by habit or compulsion. Addiction is pathological because negative states powerfully increase expected drug value acutely outweighing abstinence goals.

Neuropsychopharmacology (2020) 45:720-735; https://doi.org/10.1038/s41386-020-0600-8

\section{BRIEF INTRODUCTION TO THEORIES OF ADDICTION}

Scientific and clinical theories seek to explain why addicts continue to take drugs despite experiencing consequential harms. This paper evaluates evidence for just three accounts of addiction - goal-directed choice under negative affect, habit and compulsion-to try and determine which mechanism plays the most important role in addiction. A brief summary of the broad scope of addiction theory follows [1], to place these three accounts in context.

Withdrawal-based negative reinforcement accounts argue that although euphoric drug effects maintain initial use, growth in the adverse withdrawal syndrome drives persistent drug use [2-4]. The self-medication account specifies psychiatric symptoms, which increase during abstinence, as the main driver of persistent drug use [5]. Although individual sensitivity to a multidimensional withdrawal syndrome and other negative states is associated with problematic substance use, there remains debate as to which component of withdrawal is most important [6], how this relates to psychiatric comorbidity [7, 8], and whether negative states prime drug seeking automatically [9] or via value-based decision making $[10,11]$. This work forms the basis of the goal-directed choice under negative affect account evaluated at length later.
Positive reinforcement theories, by contrast, argue that the excessively rewarding effects of drugs drive persistent drug use independently of the withdrawal syndrome [12-15]. The challenge for positive reinforcement theories is to explain why drug use persists when addicts claim the drug has lost its value [16]. To solve this contradiction, a range of secondary processes have been postulated wherein drug seeking becomes less controlled. Theories that appeal to appetitive Pavlovian conditioning, for instance, argue that the pairing of drug cues with drug reward endows drug cues with capacity to elicit drug seeking, and sensitivity to this effect may underpin dependence [1, 17-20], because cue-reactivity is automatic [21], or because drug cues signal the accessibility (and hence greater utility) of the drug in the presence of drug cues [22, 23]. However, drug cue-reactivity is not reliably associated with dependence severity in humans [24-27], suggesting this mechanism probably does not underpin addiction.

Other positive reinforcement accounts have argued drugseeking behaviour becomes involuntary (or 'crystalized' [28]) with practice. These theories argue that drug cues, or contexts, or the completion of a prior link in a drug seeking chain, elicit drug seeking 'automatically' in the sense of not being determined by drug craving [29], or 'habitually' in the sense of not being

${ }^{1}$ School of Psychology, University of Exeter, Washington Singer Building, Perry Road, Exeter EX4 4QG, UK

Correspondence: Lee Hogarth (L.hogarth@exeter.ac.uk)

Received: 5 July 2019 Revised: 9 December 2019 Accepted: 18 December 2019

Published online: 6 January 2020 
determined by an expectation of the current value of the drug [30], or 'compulsively' in the sense that costs associated with drug seeking are discounted and do not impinge on the behaviour $[31,32]$. The habit and compulsion models are evaluated at length later.

Neurocognitive versions of positive reinforcement theory claim that although drug reward drives greater drug use, the persistence of this behaviour in addicted individuals is driven by acquired dysfunction in decision-making capacity. These accounts differ in focus. Addiction could be driven by global impairments in cognitive function [33], loss of volume/function of the prefrontal cortex and other brain regions [34], specific impairments in inhibitory control [35], or specific narrowing of temporal horizon such that future costs and benefits are not considered in decision making [36]. It remains unclear to what extent these neurocognitive dysfunctions can be methodologically isolated from each other, and whether they play a causal/prospective role in addiction or are non-functional consequences of drug exposure [37]. These neurocognitive models will not be considered further because there is insufficient space to do justice to this broad field.

The various theories for addiction are usually pitted against one other on the assumption that only one mechanism can explain addiction. However, multiple mechanisms could contribute simultaneously. Furthermore, the underpinning mechanisms could differ between individuals depending on developmental pathway, constitution, risk and protective factors [38, 39], or between drug classes, for example, stimulants vs. depressants [40], or across types of behaviour, for example, drug seeking vs. drug taking $[41,42]$. However, methods do not exist to adequately isolate the contribution of specific mechanisms to behaviour in different conditions.

Box 1 defines the three theories of addiction evaluated in this paper, alongside key methods used to test each theory in laboratory animals and humans-providing a translational perspective. The methods used with each species are descriptively similar and arguably tap the same theoretical mechanisms, but multiple methodological differences make direct comparison between species challenging. Despite these complications, the weight of evidence does appear to provide converging translational support for the claim that addiction is primarily driven by excessive goal-directed drug choice under negative affect, and to a lesser degree by habit or compulsion.

\section{IS ADDICTION PRIMARILY DRIVEN BY EXCESSIVE GOAL- DIRECTED CHOICE UNDER NEGATIVE AFFECT?}

Studies with laboratory animals

This section will consider animal studies that test whether dependence vulnerability is due to greater expected drug value driving goal-directed drug seeking, particularly in negative states [43]. Drug value can be measured by giving laboratory animals a mutually exclusive choice between a response that earns the drug and a response that earns another reward such as food. The proportion of drug choices quantifies the relative value of the drug. Only some 'vulnerable' animals show preferential drug choice [44-46]. Drug choice can be increased by extended drug exposure $[47,48]$, and modified by manipulating the relative magnitude, delay or effort associated with the two rewards [49-59] and by the opportunity for social interaction [60, 61]. Thus, drug choice is modified by individual differences, and multiple decision parameters relevant to that choice.

The claim that animals make goal-directed choices between drug and food based on the expected relative value of the rewards is supported by two lines of evidence. First, rats that preferentially choose drug over food have a greater number of neurons in the orbitofrontal cortex (OFC), which selectively activate prior to performance of the drug choice, as if the ramping up of OFC neuronal activity is the genesis of the drug choice
Box 1: Definitions and methods of three addiction theories Definitions

Theory $1-$ Goal-directed drug choice under negative affect

On this view, individuals differ in their experience of drug reward value, due to a variety of constitutional risk factors. The frequency of goal-directed drug seeking is driven by an expectation of drug value (determined by experienced value) combined with knowledge of the voluntary behaviour necessary to obtain the drug $[8,15,297-299]$. The second process is that for some users, negative states (withdrawal, distress, pain, anxiety, depression etc.) are acutely mitigated by drugs, enabling these negative states to powerfully raise expected drug value (reflected in verbal 'coping motives'), driving goal-directed drug seeking above already elevated baselines $[10,11]$, acutely outweighing competing abstinence goals [300].

Theory 2-Habit.

Drug seeking is initially goal-directed, but drug reinforcement progressively strengthens the association between drug stimuli $(S)$ and the drug-seeking response $(\mathrm{R})$, such that drug stimuli can elicit the drug-seeking response directly through an $\mathrm{S}-\mathrm{R}$ association, without retrieving an expectation of drug value [30]. Addiction is driven by an increased contribution of this $\mathrm{S}-\mathrm{R} /$ reinforcement mechanism to the control of drug seeking. Habit theory predicts that drug seeking is controlled by the established $\mathrm{S}-\mathrm{R}$ strength only so long as the reinforcer is not re-experienced has having a different value. Once the reinforcer is experienced as having a lower or higher value, this will change the strength of the $\mathrm{S}-\mathrm{R}$ association and the frequency of drug seeking will change accordingly (i.e. habitual drug seeking is flexible, but requires experience of the changed value of the drug to adapt).

Theory 3-Compulsion

Compulsion theory is akin to habit theory, except that the flexibility of drug seeking is argued to be lost. As with habit theory, drug seeking is argued to be goal-directed initially, and then transitions to become an $\mathrm{S}-\mathrm{R}$ habit, but then in the third stage, becomes a compulsion- $\mathrm{a}$ maladaptive habit where the $\mathrm{S}-\mathrm{R}$ association controlling drug seeking can no longer be modified by direct experience of the drug reinforcer [31, 32]. Because compulsive drug seeking is controlled by the established $\mathrm{S}-\mathrm{R}$ association (and not by the $\mathrm{S}-\mathrm{R} /$ reinforcement mechanism) drug seeking is not modified by direct experience of the low value of the reinforcer and so continues in perpetuity despite loss of value. This explains why drug seeking persists even though drug use is directly experienced as harmful, because this does not weaken the $\mathrm{S}-\mathrm{R}$ association controlling drug seeking.

\section{Methods}

Stress-induced reinstatement in laboratory animals: In the reinstatement model laboratory animals are first trained to self-administer an addictive drug. The response is then extinguished by omitting the drug, and responding declines. In the reinstatement test, animals are exposed to stress vs. no-stress (manipulated behaviourally or pharmacologically), and it is typically found that stress increases (reinstates) drug self-administration [83].

Mood/stress-induced drug motivation in humans: Human drug users are exposed to negative mood or stress induction via a range of methods (music, selfreferential statements, mood congruent words, public speaking, cold pressor, heat pain, serial addition, video clips, guided imagery etc.), and contrasted to a no-induction control condition (either between-subjects or counterbalanced within-subjects). Drug motivation is measured post-induction via a range of methods (craving, choice, consumption, cognitive bias, economic demand etc.). It is typically found that drug motivation is increased in the induction vs. noinduction condition (sometimes also relative to pre-induction), demonstrating the ability of negative states to motivate drug seeking [7, 10, 301, 302].

The outcome-devaluation task in laboratory animals: Animals first learn an instrumental response to produce an appetitive reward. The response could be goal-directed (driven by an expectation of current reward value), or habitual (driven directly by an $\mathrm{S}-\mathrm{R}$ association). To test this, the reward is devalued (in one group) by pairing it with lithium chloride-induced sickness or specific satiety (in a separate context so that the test context is not paired with the devaluation treatment). Then, at test, animals again have the opportunity to perform the instrumental response in extinction (so experience of the reinforcer cannot modify any $\mathrm{S}-\mathrm{R}$ association controlling the response). The response is deemed goal-directed in being controlled by an expectation of the current value of the reward if the devalued group decreases responding in the extinction test. If they do not show a devaluation effect, the response is deemed habitual in being controlled directly by an $\mathrm{S}-\mathrm{R}$ association. Four versions of this method have been used to test whether drugs promote habitual behaviour, as outlined in the text $[30,174-176]$.

The outcome-devaluation task in humans: Typically, participants learn that two responses (R1 and R2) earn different rewarding outcomes (O1 and $\mathrm{O} 2)$. One outcome is then devalued by consumption to satiety or instructions that an outcome is no longer available. Finally, choice between the two responses is tested in nominal extinction (i.e. instructions that outcomes will not be signalled until the end). A decrease in responding for the devalued outcome suggests that the response is goal-directed in being controlled by an expectation of the current value of the outcome. But if responding for the devalued outcome does not decrease (relative to baseline, or non-devalued control group), then the response is deemed habitual in being elicited directly by an $\mathrm{S}-\mathrm{R}$ association $[111,130,199-203,303]$ 
The two-stage task in humans: In each trial, selecting one stimulus from the firststage pair produces a 'common' and 'rare' second-stage pair with a 70:30 probability, respectively. If the other stimulus from the first-stage pair is selected, the probabilities of the second-stage pairs are reversed. Selecting a second-stage stimulus pays an amount that varies slowly over trials independently for each stimulus. Payoff is maximised by learning the transitional structure between stages and which second-stage stimulus currently pays most. The goal-directed (model-based) vs. habitual (model-free) status of responding is determined by the choice of first-stage stimulus following a trial where a stimulus from the rare second-stage pair paid most. Goal-directed participants will choose the other first-stage stimulus than they chose in the previous trial, giving a $70 \%$ chance of producing the same second-stage pair as the previous trial, to access the secondstage stimulus that paid most. By contrast, habitual participants will choose the same first-stage stimulus as they chose on the previous trial because that previous trial was reinforced, even though this choice gives only a $30 \%$ chance of producing the same second-stage pair as the previous trial. In short, the task measures whether participants make choices using knowledge of the transitional structure between stages, or simply repeat choices that paid off in the previous trial [229, 233, 278-281].

Shock punishment of self-administration in laboratory animals: Animals are first trained on a drug self-administration schedule (or seeking-taking chain, where an initial response is required to access the self-administration lever). After training, the self-administration response is punished by foot shock to quantify the decrease in responding relative to baseline and/or a no-punishment group. Compulsivity is indexed by less shock suppression of self-administration $[60,197,283-295]$

$[62,63]$. The OFC also carries signals reflecting multiple dimensions of rewards such as magnitude, effort, delay etc., suggesting the OFC may be important in calculating the overall utility of rewards [64]. Finally, although there is a question of homology [65], the OFC plays a role in goal-directed decision making in humans [66], which may translate to animals.

The second line of evidence comes from the outcomedevaluation procedure used to determine whether behaviour is goal-directed [67] (see Box 1). In one study [68], rats were trained on a seeking-taking chain for cocaine before the taking lever was extinguished. This manipulation immediately reduced performance of the seeking response tested in extinction (in the absence of the taking lever), suggesting the seeking response was controlled by a goal-directed expectation of access to cocaine, rather than an $\mathrm{S}-\mathrm{R}$ association. So although drug seeking can be goal-directed (see also [69-71]), as noted in the habit section, most animal studies suggest it is habitual (see also [72]). It remains unclear what the optimal parameters are for detecting goaldirected vs. habitual drug-seeking behaviour [73].

The most important question is whether negative states such as withdrawal and stress can motivate goal-directed drug seeking. The key study testing this prediction [74] found that when shifted to a state of heroin withdrawal, rats immediately increased their heroin seeking in extinction, suggesting withdrawal raised the expected value of heroin as a goal. Relatedly, other animal studies have demonstrated that withdrawal or conditioned withdrawal motivate drug vs. food choice, or reinstate drug self-administration, or activate negative emotional brain circuits. However, these motivational effects may not necessarily be goal-directed, there are several null effects to consider, and it is possible that the motivational impact of withdrawal may differ between drug classes [75-82].

The stress-induced reinstatement model has also produced mixed support for the goal-directed account (see Box 1). Behavioural and pharmacological stress induction procedures reliably increase single lever drug seeking and taking in the reinstatement model $[83,84]$. Furthermore, sensitivity to this effect is increased by various 'vulnerability' factors: specifically, long vs. short access to drugs [85-88]; adolescent vs. adult onset of drug exposure [89, 90]; oestrous cycle [91]; individual heterogeneity [92]; protracted withdrawal [93]; and baseline anxiety level at test [94]. This work suggests that sensitivity to negative-affect-driven drug seeking may play a role in vulnerability to dependence [95]. However, it is not clear whether stress augments drug seeking by raising the expected value of the drug, or through a more automatic form of control [96]. Furthermore, a wide range of nonstress variables prompt reinstatement suggesting it may be a noisy index of emotional control of behaviour [97]. Finally, one study has found that yohimbine-induced stress did not increase drug over food choice (Ahmed et al., personal communication 2019). In sum, the studies reviewed here provide suggestive but preliminary evidence that drug seeking in laboratory animals can be goal-directed in some conditions, that withdrawal (and possibly stress) may motivate goal-directed drug seeking, and that individual variation in this motivational effect could underpin dependence vulnerability. However, more work is needed to convincingly determine that addiction in laboratory animals is driven by excessive goal-directed drug choice under negative affect.

\section{Human studies}

This section will consider human evidence that drug dependence is associated with excessive goal-directed drug choice, especially under negative affect. Dependence symptom severity is consistently associated with greater economic demand (willingness to pay) for drugs, in both non-clinical [98-100] and clinical samples [101-103]. Economic drug demand also predicts treatment outcomes [99, 104], and drug consumption [105], and is increased by withdrawal [106, 107], stress induction [108], impulsivity [109], depression, anxiety [110] and schizophrenia [102]. To the extent that drug demand reflects expected drug value, these studies support the claim that goal-directed drug seeking increases with dependence and negative affect states (withdrawal, stress induction, psychiatric symptoms).

Excessive drug value indexed in human concurrent choice tasks is also associated with dependence. Participants make forced choices between drug and natural reinforcer over a series of trials. Different designs use points for rewards [111, 112], pictures of rewards [7, 113-117] or consumption of rewards [14, 118-124]. Preferential drug choice is reliably associated with the severity of dependence to heroin [125], cocaine [116, 117, 126, 127], alcohol $[10,15,26,112,113,115]$, and tobacco [15, 111, 114, 124, 128]. These associations have been found in both clinical $[15,113,114,116,117,125-127]$ and non-clinical samples $[10,26,111-113,115,128]$. Percent drug choice also increases with latency to relapse [129], abstinence [7], depression and anxiety symptoms and self-reported drinking to cope with negative affect $[10,15,113,115]$, and is decreased by health warnings and satiety $[111,130,131]$, by raising the magnitude of the alternative reward [14, 112, 118, 121, 132-134], and by increasing the effort [59], and delay of the drug choice $[112,133,134]$. Thus, like economic demand, concurrent choice tasks index drug value, and this is increased in individuals with dependence and associated psychiatric risk factors.

The crucial question is whether drug choice is goal-directed as opposed to automatic. In support of the goal-directed account, drug choice is immediately reduced in extinction by decreasing the value of the drug via satiety $[11,111,135]$, pharmacotherapy $[130]$ and health warnings $[111,135]$, indicating that drug choice is goal-directed (see outcome-devaluation task in Box 1). The implication is that preferential drug choice in dependent individuals is controlled by greater expected drug value.

Crucially for the theoretical model, goal-directed drug choice has also been augmented by negative affect induction in two studies. In the first study, smokers were trained on a concurrent choice task to earn tobacco and food points, before tobacco was devalued by specific satiety [11]. Participants then completed either a negative or positive mood induction procedure before choice was measured again in extinction. For participants in the positive mood induction group, satiety decreased goal-directed tobacco choice as expected $[111,135]$. By contrast, participants in the negative mood induction group who reported an increase in 
negative mood actually increased their goal-directed tobacco seeking, despite smoking satiety. The implication is that negative mood is a powerful motivational state driving goal-directed tobacco seeking that can outweigh the primary motivational state of satiety. In the second study, alcohol drinkers were trained on a concurrent choice task for alcohol and food points before being tested in extinction with a negative or positive affect statement read at random prior to each choice [10]. Negative affect statements primed an increase in goal-directed alcohol choice, relative to positive statements and baseline, in participants who reported drinking to cope with negative affect. The implication is that negative affect augments goal-directed drug choice, and this effect is magnified in those who are constitutionally predisposed to use drugs to cope with negative affect.

Other studies have demonstrated that, in vulnerable individuals, $\mathrm{mood} / \mathrm{stress}$ induction has a greater priming effect on drug motivation measured by pictorial drug choice, craving, economic demand and consumption. The stress-induced increase in drug craving predicts risk of relapse in alcohol [136-139] and cocainedependent individuals [140, 141], suggesting this sensitivity is a core mechanism in addiction. Mood/stress-induced drug motivation is also amplified in individuals who self-report using drugs to cope with negative affect [10,115, 125, 136, 137, 142-149], in smokers with depression symptoms $[7,150]$, young adult drinkers with depression symptoms [10] and alcohol-dependent men with anxiety symptoms [137]. Individual sensitivity to mood-induced drug seeking also correlates with withdrawal-induced drug seeking suggesting a common mechanism [7]. Importantly however, although alcohol dependence has been associated with greater mood/stress-induced drug motivation in some studies [147, 151-153], a sizable number of other studies have reported null associations $[10,113,115,137,143,146,148,149,154]$. The implication is that although dependence severity is associated with preferential goal-directed drug choice, negative affectinduced priming of drug motivation is predominantly linked to psychiatric symptoms and drug use coping motives, and this second process may represent the unique additional risk factor that drives addiction in those with psychiatric comorbidities and subclinical psychiatric symptoms.

Psychiatric symptoms, abuse/trauma history and associated drug use to cope with negative affect are major prospective risk factors for the development and persistence of drug dependence [155-173]. Furthermore, as shown in Table 1, self-reported drug use to cope with negative affect mediates the relationship between psychiatric/abuse/trauma severity and dependence severity, in a wide range of clinical and subclinical groups. Although the majority of studies listed in Table 1 are crosssectional, precluding causal inferences, they nevertheless strongly support the hypothesis that drug dependence in a wide range of vulnerable groups is driven by excessive goal-directed drug choice under negative affect.

\section{IS ADDICTION DRIVEN BY HABIT LEARNING?}

According to habit theory of addiction [30,32], repeated experience of drug reward progressively strengthens the stimulus-response $(\mathrm{S}-\mathrm{R})$ association between drug stimuli and the drug seeking responses, such that drug stimuli become able to elicit drug seeking directly, without an expectation of the drug and its current value. Thus, drug seeking becomes less susceptible to voluntary control and decision making [30,32]. The outcome-devaluation and twostage procedures are the key sources of evidence for the habit account, and these studies are reviewed now.

Studies with laboratory animals

Outcome-devaluation designs testing habit theory of addiction in animals fall into four categories. In the most compelling designs, animals learn that two responses earn drug and food in separate sessions. Then, in separate tests, each outcome is devalued and response rate for the devalued outcome is measured in extinction. Four such designs have found that the drug-seeking response does not decrease from baseline following devaluation, suggesting the behaviour is not goal-directed (controlled by expected outcome value), but is an $\mathrm{S}-\mathrm{R}$ habit elicited by drug paired contextual stimuli [30, 174-176]. The food-seeking response, by contrast, is reduced by devaluation, indicating that it is goaldirected. These four studies provide the core empirical basis for the claim that drug seeking as opposed to natural reward seeking (in laboratory animals) is especially prone to habitual control.

In the second design, animals are chronically exposed to a drug (experimenter administered or consumed in the home cage), and then trained on a single lever for food. Food is then devalued, and the food-seeking response is tested in extinction. Eight such studies have shown that, at test, food seeking is insensitive to devaluation (habitual) in drug-exposed animals and sensitive to devaluation (goal-directed) in non-drug-exposed animals [69, 177-183], although three studies reported null group differences [184-186]. The implication is that chronic drug exposure renders reward seeking prone to habitual control, producing general behavioural autonomy. However, it is not clear how habitual natural reward seeking would lead to drug dependence.

In the third design, animals are trained on a single lever for drug, and sensitivity to devaluation is tested after minimal vs. extended training. Three studies have demonstrated that the drug-seeking response is initially goal-directed but then becomes habitual with extended training [69-71]. However, because food seeking also transitions from goal-directed to habitual control with training in animals [187] (not replicated in humans [188]), these findings do not inform us about the unique habit forming potential of drug seeking.

In the fourth design, animals are trained on a single lever for drug and tested for sensitivity to devaluation following a fixed amount of training. These studies have revealed drug seeking to be both goal-directed [68, 74], and habitual [189], so do not inform us about the unique habit forming potential of drug seeking.

There are two main criticisms of the animal outcome-devaluation model. First, habitual instrumental behaviour is generally only found when animals have access to a single lever in each session ([190, 191] but for one exception see [30]). By contrast, it is commonly found that when rats have concurrent access to two levers for different rewards in each session, drug seeking remains goal-directed [73], food seeking remains goal-directed despite chronic drug exposure [184, 192], and food seeking remains goaldirected despite extended training [193-196]. If one accepts that human drug users' natural environment offers a multitude of responses for different rewards, then it must be concluded that habitual behaviour seen in the animal model has minimal ecological validity and likely does not play a major role in human addictive behaviour [197, 198].

The second criticism is that habitual control is fragile because sensitivity to devaluation is immediately restored in reacquisition tests where drug seeking produces the devalued reinforcer. This restoration of sensitivity to devaluation in reacquisition tests is found for both drug seeking [30, 174-176] and food seeking in chronically drug-exposed animals [180, 181]. If one accepts that in human drug users' natural environment, extinction conditions rarely occur, but conditions comparable to reacquisition prevail (i.e. drug seeking is typically reinforced), then it must be concluded that the habitual behaviour seen exclusively in the extinction test of the animal model has limited ecological validity and likely does not play a major role in human addictive behaviour.

Human studies

Table 2 summarises outcome-devaluation studies conducted with human drug users to test habit theory. There have been 11 tests published in 7 papers [111, 130, 199-203]. A scan of the 'Support 


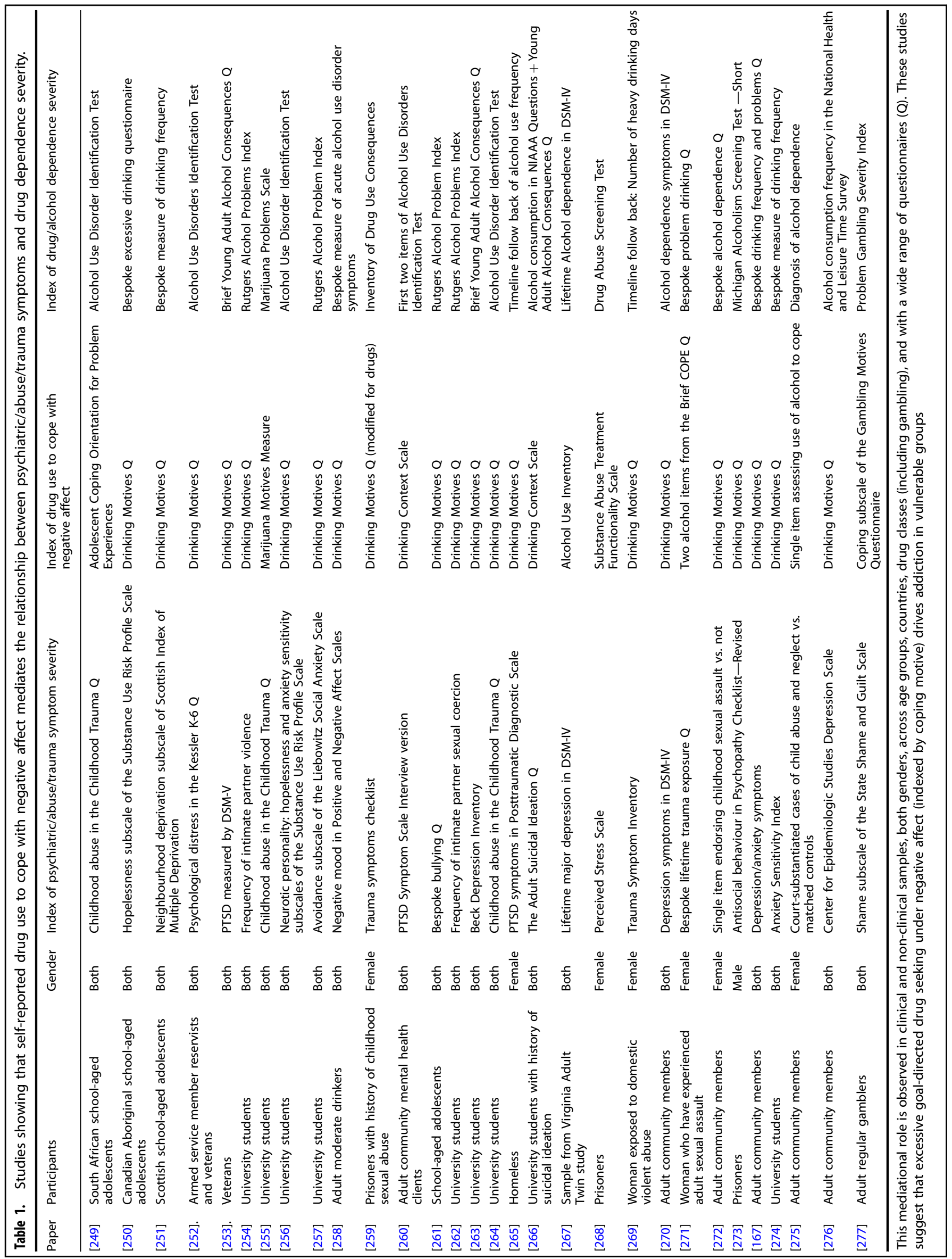




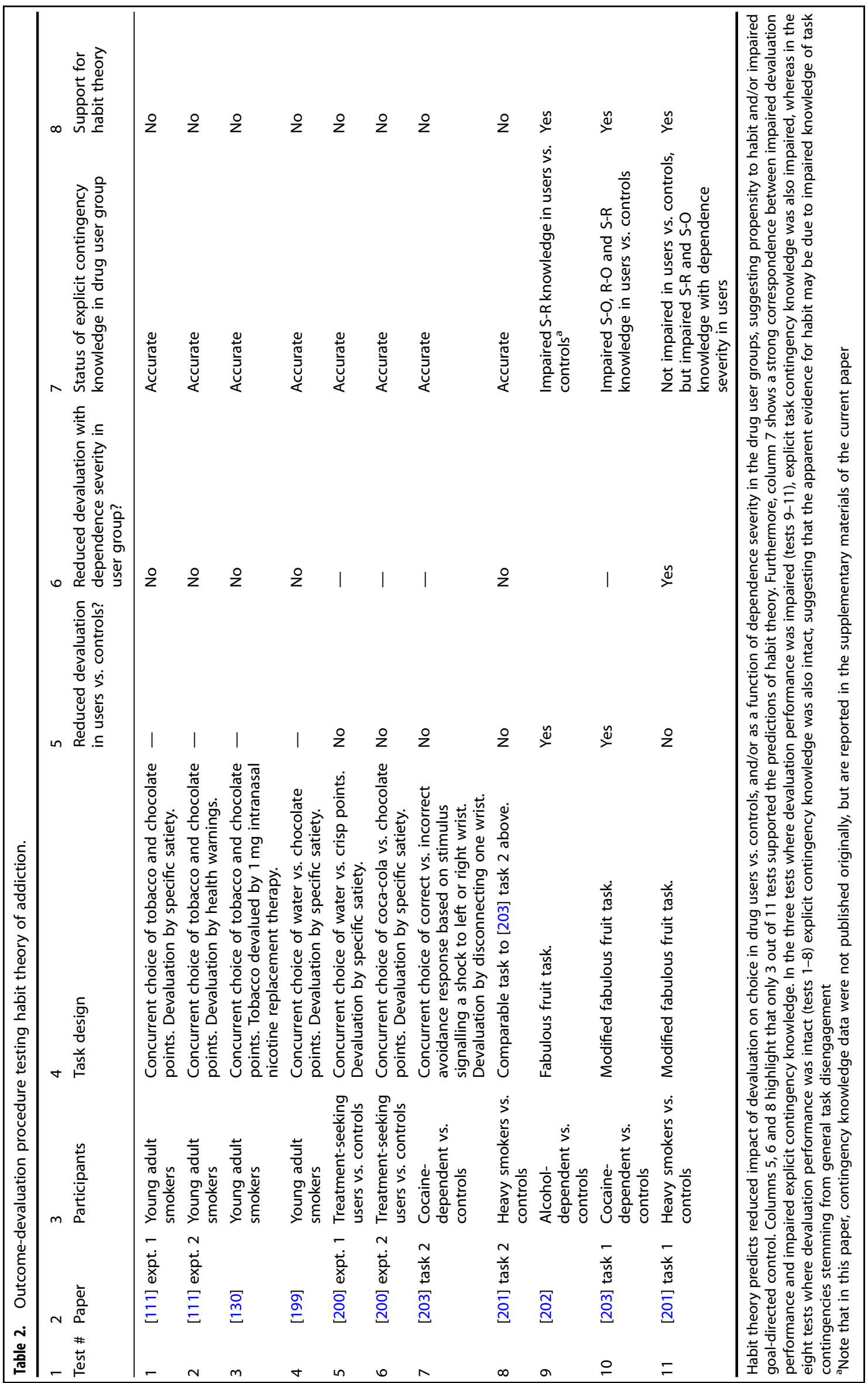


726

for habit theory' column indicates that these tests yield an 8 to 3 ratio of evidence against habit theory. Additionally, the analysis below indicates that the three positive tests can be explained by general task disengagement producing impaired explicit knowledge of task contingencies, rather than a specific propensity to habit learning.

All the studies in Table 2 used an outcome-devaluation task in which there was a concurrent choice between two responses that earned different rewards. These rewards could be points for tobacco, food, soft drinks, or money plus a specific outcome picture, shock or aversive noise. Outcomes were then devalued by specific satiety, by instructing participants that outcome pictures would not earn money points, or by disconnecting the shock or noise. Finally, participants were tested for choice between responses in extinction. If participants show reduced choice of the response that led to the now devalued outcome, they are goal-directed, but if they do not reduce choice of the devalued outcome, they are habitual.

Habit theory predicts that the effect of devaluation on choice at test should be reduced in drug users vs. controls, and/or as a function of dependence severity in the user group, demonstrating a propensity to habit. Columns 5 and 6 of Table 2 summarise evidence for these predictions. Tests numbered 1-8 provide no evidence for habit theory, in that the devaluation effect was not reduced in the drug user group or as a function of dependence severity. This failure to support habit theory was found in both clinical (tests 5-8) and non-clinical samples (1-4). Furthermore, the failure to support habit theory cannot be attributed to the use of concurrent choice procedures (which tend to discourage habitual learning as noted earlier) because all of the tests in Table 2 used concurrent choice procedures, both those that failed (test 1-8) and those that notionally supported habit theory (test 9-11).

In those tests that supported habit theory (tests 9-11), the drug user group or more dependent users also showed impaired explicit knowledge of the contingencies operating in the task, in addition to weaker devaluation performance. Indeed, column 7 shows a perfect correspondence between impaired explicit contingency knowledge and impaired devaluation performance. In numerous human learning tasks, explicit knowledge of task contingencies is necessary for accurate performance, that is, participants who have impaired contingency knowledge perform less accurately in these tasks [204-209]. The implication is that drug users, or more dependent users, failed to acquire explicit contingency knowledge in the three tests supporting habit theory (tests 9-11), which impaired their devaluation performance, making them appear to be habitual. Drug users have general deficits in cognition or motivation that underpin their performance deficits in wide range of tasks [37, 210-212]. Arguably, this general deficit in cognition or motivation produced general task disengagement that impaired explicit contingency knowledge and thereby impaired devaluation performance. In other words, impaired devaluation performance is probably not driven by a specific propensity to habit learning or deficit in goal-directed control but by general task disengagement.

It is important to note that drug users' deficit in explicit contingency knowledge extended to knowledge of stimulus -response $(S-R)$, response-outcomes $(R-O)$ and stimulus-outcome $(\mathrm{S}-\mathrm{O})$ contingencies. Thus, it cannot be claimed that drug users were specifically impaired in learning about outcomes important for goal-directed action, as has sometimes been claimed [201, 213]. For example, the supplemental material for test 10 [203] states that: "Compared with control volunteers, CUD [cocaine dependent participants] demonstrated significant deficits in explicit knowledge in terms of stimulus-outcome ... responseoutcome ... and stimulus-response ... relationships". Similarly, in test 11 [201], "Strong evidence was obtained for a negative association between FTND scores [nicotine dependence severity in smokers] and explicit knowledge on stimulus-response... and stimulus-outcome associations". Furthermore, hierarchical multiple regression analysis suggested that weaker knowledge of the stimulus-outcome contingencies explained the relationship between nicotine dependence severity and weaker devaluation performance, leading the authors to conclude that "habitual responding in severely dependent smokers may be the result of compromised goal-directed learning". However, because this specific impairment in stimulus-outcome knowledge was not found consistently across the three studies supporting habit theory, this conclusion cannot be maintained. Indeed, test 9 [202] did not publish the explicit contingency knowledge data, but later analysis of these data (reported in the supplementary materials of the current paper) found less accurate explicit knowledge of stimulus-response contingencies in alcohol dependent vs. control participants-the very knowledge that should be important for habit learning. In sum, all three studies showing impaired devaluation performance also showed impaired explicit contingency knowledge suggesting that the apparent evidence for habit could be explained by general task disengagement perhaps driven by a general cognitive impairment [37, 210-212].

The idea that devaluation performance could be disrupted by general cognitive impairment is supported by 'cognitive load' studies in humans and animals. These studies have found that devaluation performance can be impaired by stress [214-219], acute alcohol administration [220], an alcohol consumption expectancy [135], being placed in drug-related contexts $[221,222]$, and sleep deprivation [223]. Furthermore, devaluation performance is impaired in a range of neuropsychiatric conditions including social anxiety [224, 225], autism spectrum disorder [225], schizophrenia [226], Parkinson's disease [227], obsessive compulsive disorder [213], impulsivity [199], and in young children [228]. The generality of the devaluation deficit suggests it stems from general motivational or cognitive impairments, and is not the unique mechanism underpinning addiction.

A similar analysis may be applied to the two-stage task (see Box 1 for a description of the methods). The results of these studies are summarised in Table 3. There have been nine tests of whether model-based (goal-directed) learning is impaired or model-free (habit) learning is increased in drug users vs. controls (column 4), or as a function of dependence severity in the user group (column 5). Of the nine tests, only four claimed evidence for habit theory (although one of these was one-tailed and the group difference was not significant when a confound in cognitive speed was controlled [229]). Crucially, none of the studies measured participants' explicit knowledge of the task contingencies. Consequently, it is unknown whether the four studies reporting evidence for habit theory can be explained by impaired contingency knowledge (as was the case with the outcomedevaluation procedure). However, it is known that model-based learning can be increased by adding incentives (points) for accurate performance [230], and impaired by a working memory load manipulation [231], and is impaired in individuals with lower working memory capacity [232], and lower cognitive speed $[233,234]$. These findings suggest that the four two-stage studies that reported evidence for habit theory may be attributed to general motivational/cognitive deficit in drug users or as a function of dependence severity, rather than a specific propensity to habit learning or deficit in goal-directed control. To quote one two-stage paper [233]: "whether reduced model-based control in patients constitutes a disease-specific mechanism or results from general cognitive impairments can only be teased apart in future longitudinal studies".

\section{IS ADDICTION DRIVEN BY COMPULSION (INSENSITIVITY TO PUNISHMENT)?}

Studies with laboratory animals

One of the major problems with habit theory noted earlier is that sensitivity to devaluation is restored immediately when responses 


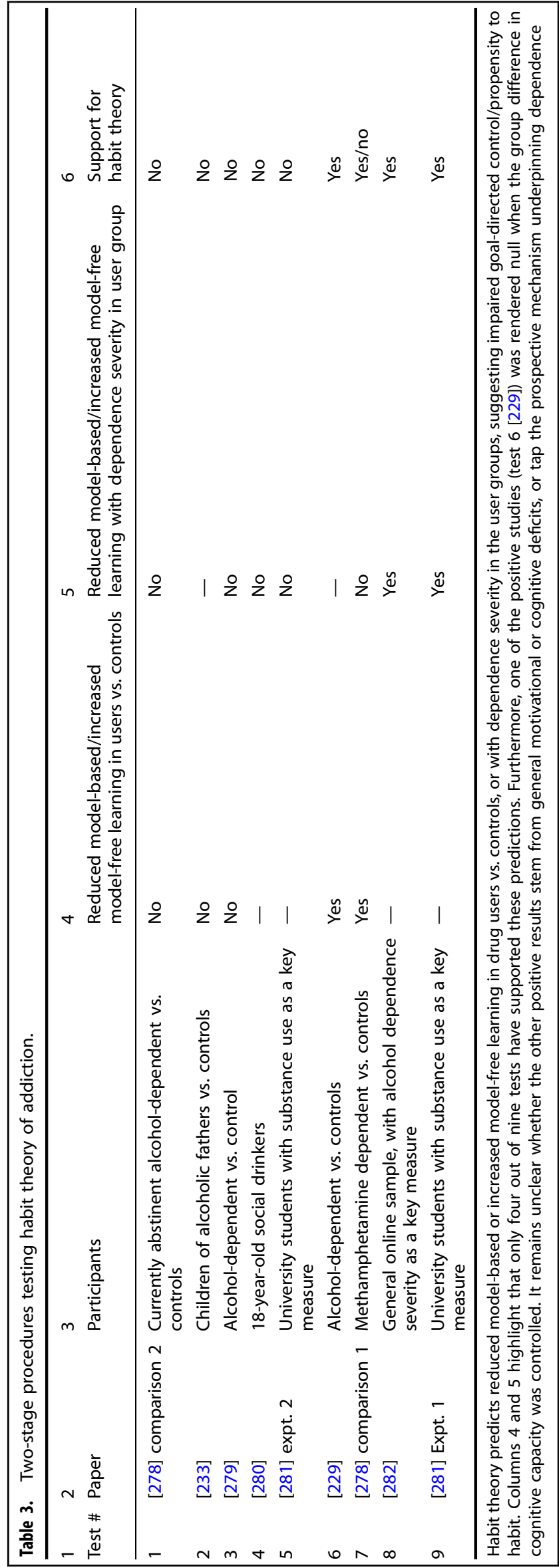

produce the devalued reinforcer, so habit could not explain the persistence of drug seeking in the human natural environment. To negate this theoretical dilemma, it has been proposed that drug seeking is controlled by compulsion, defined as "a maladaptive stimulus-response habit" [31], and "as the maladaptive persistence of responding despite adverse consequences" [32] (it should be noted that other researchers use the term compulsion to mean a wide range of processes which are not considered here because they are difficult to test empirically [198]). The principal assay of compulsivity is the persistence of punished drug seeking. The problem, however, is that persistence of punished drug seeking can equally be explained by excessive value ascribed to the drug, outweighing the punisher [43]. Unique evidence for the compulsion model relies on demonstrating that persistence of punished drug seeking is not associated with excessive valuation of the drug in another assay. Early studies presented preliminary support for this dissociation between assays, but later studies that have employed more sensitive measures of drug value have indicated that persistence of punished drug seeking is associated with greater valuation of the drug, undermining the core behavioural evidence for compulsion theory.

Table 4 summarises studies that have measured the suppression of drug self-administration by shock punishment (the putative assay of compulsivity), and drug value in a second assay (e.g., self-administration frequency, breakpoints in progressive ratio tasks, persistence under extinction, and preferential choice of drug vs. natural reward). Studies reporting a dissociation between these two assays (column 5) support compulsion theory by suggesting that persistence under punishment cannot be explained by greater drug value. By contrast, studies reporting a correlation between these two assays contradict compulsion theory by suggesting that persistence under punishment may be due to greater drug value. Column 5 indicates that four studies support compulsion theory, and 11 studies support drug value theory. Overall, the evidence favours drug value over compulsion theory as an explanation for the persistence of punished drug seeking. One speculation is that vulnerable animals persist under punishment not because they are insensitive to costs, but because the punisher motivates drug self-administration in the following period to self-medicate. If this is true, then persistence of punished drug seeking could be another example of excessive goal-directed drug seeking under negative affect, not an example of compulsion.

Human studies

Human studies designed to test whether dependence is associated with insensitivity to costs (cost discounting) have also provided minimal evidence for compulsion theory. Demand tasks measure the amount of drug participants would hypothetically consume across increasing prices (costs). The intensity of demand (maximum consumption at low price) is considered to be a relatively pure index of drug value unaffected by costs. By contrast, breakpoint - the price at which drug consumption drops to zero-is thought to be more sensitive to the impact of price costs on the decision to consume. Compulsion theory would be supported if dependence severity was more strongly associated with breakpoint than intensity, suggesting cost insensitivity is more important than drug value [235-237]. However, metaanalyses and systematic reviews of this literature have found that proxies for dependence correlate more consistently with measures of intensity than breakpoint [238-241], suggesting that dependence is more likely to be driven by greater drug value than cost discounting. However, one key study found that student drinkers with a family history of alcoholism were less sensitive to the effect of imagined next-day responsibilities on reducing alcohol demand [242], supporting the notion that dependence vulnerability may be linked to discounting costs imposed on alcohol. It remains to be seen what explains this discrepancy. 


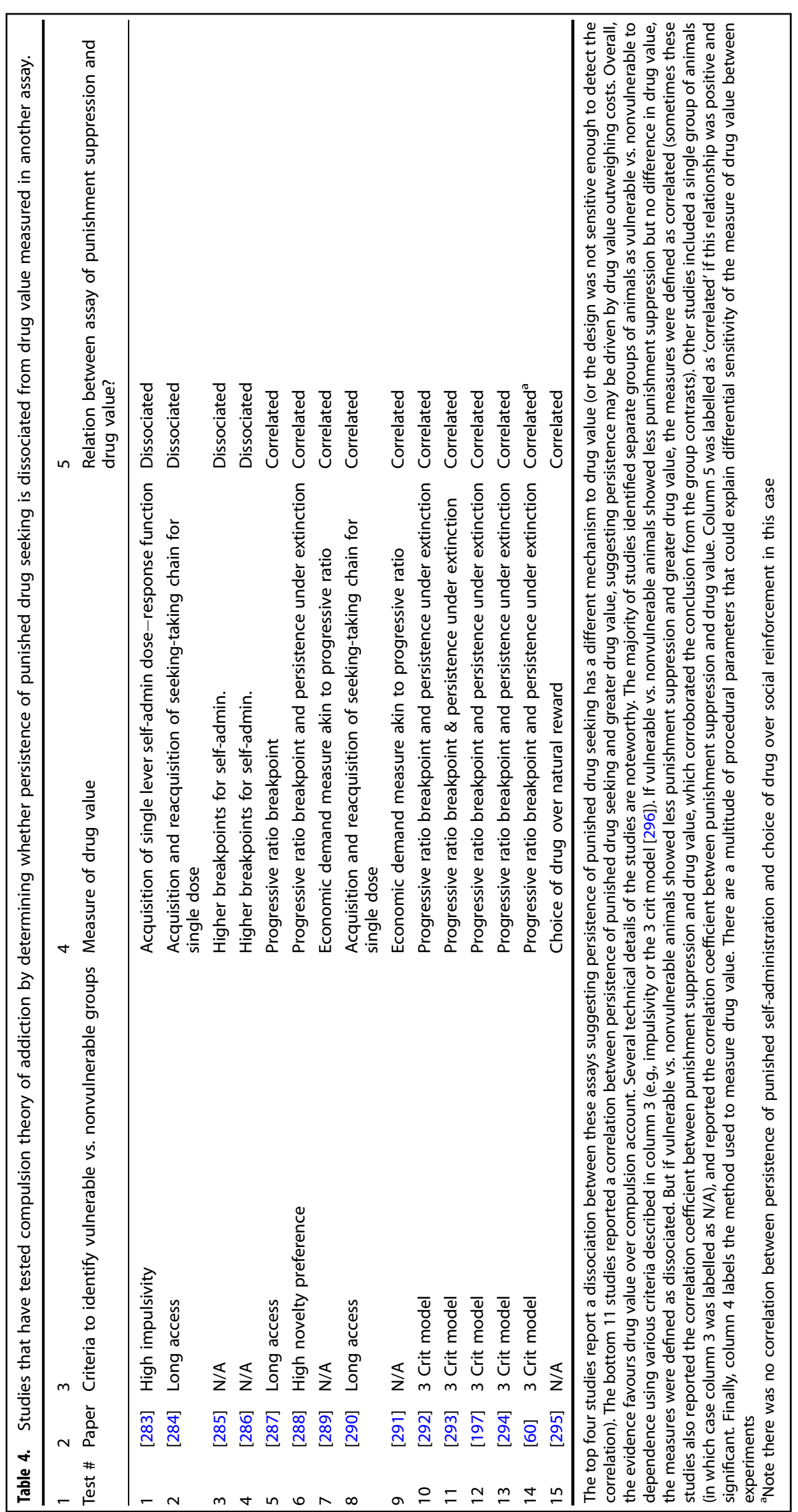


Deficits in reversal learning have been interpreted as evidence for greater cost discounting in addiction. In reversal learning tasks, participants learn that one response has a higher payoff than an alternative choice, before these response-reward contingencies are reversed. Drug users show deficits in reversal learning despite comparable acquisition of the initial contingencies [35, 243-245] (for similar findings with laboratory animals see [246, 247]). One interpretation is that drug users are less sensitive to the punishment of the incorrect choice, driving persistence of this choice. However the effect could also be due to impaired prediction error coding, cognitive inflexibility, or general task disengagement [35]. Reversal learning deficit therefore do not provide compelling evidence for cost discounting in addiction.

A recent study directly tested whether alcohol dependence was associated with discounting delay and opportunity costs imposed on alcohol seeking [112]. Student drinkers ( $n=127$, who varied in alcohol dependence symptom severity) made concurrent forced choices between alcohol and food points under conditions that manipulated the magnitude of points and the delay to receive points. Alcohol value was indexed by preferential choice of alcohol vs. food, whereas sensitivity to costs was indexed by the decrease in alcohol choice when food points were of greater magnitude (sensitivity to opportunity costs) and when alcohol points were delayed (sensitivity to delay costs). It was found that alcohol use disorder symptom severity was associated with increased alcohol choice indicating greater value of alcohol, but not with sensitivity to opportunity or delay costs imposed on the alcohol choice. This paper provided further evidence that dependence is driven by greater value ascribed to drugs, and not with greater discounting of costs imposed on drugs, i.e. compulsion theory was not supported.

\section{SUMMARY AND CONCLUSION}

The paper reviewed studies with laboratory animal and humans that tested whether addiction is driven by excessive goal-directed drug choice under negative affect, habit, or compulsion. There was substantial support for the first account, and limited support for the latter two. Animal studies supporting the excessive goal account found that drug choice was associated with dependence vulnerability, can be modulated by multiple decision parameters, is subserved by the OFC decision-making centre, and is goaldirected. However, there was only indirect suggestive evidence that negative states such as withdrawal and stress motivate drug seeking via a goal-directed mechanism, and that this effect might be amplified in vulnerable animals. This area needs more attention, back-translating human findings. Human studies, by contrast, supported the excessive goal account by demonstrating that economic drug demand increases with dependence, psychiatric symptoms, and stress induction. Similarly, concurrent drug choice is demonstrably goal-directed, is modulated by decision parameters, and increases with dependence, psychiatric symptoms, and mood/stress induction, and this latter effect is amplified in individuals who report psychiatric symptoms and drug use to cope with negative affect, and in those at greater risk of relapse. Finally, psychiatric symptoms, abuse/trauma history, and coping motives confer prospective risk of dependence, and coping motives mediate this risk. These data provide converging translational (and longitudinal) evidence that addiction is primarily driven by excessive goal-directed drug choice under negative affect, although evidential gaps do need to be addressed.

By contrast, the evidence for habit theory is weak, suggesting that this psychological process does not play a major role in human addiction. Only four animal studies showed that drug seeking is especially prone to habit, and although eight studies showed that drug exposure renders reward seeking habitual, it is unclear how this would drive dependence. Habitual behaviour is also abolished when animals are given a choice, and when responses are rewarded, and so could not explain human addictive behaviour in the natural environment where these conditions prevail. In humans, most studies found no evidence for habitual behaviour in drug users vs. controls, or as a function of dependence. The three studies supporting habit theory showed a correspondence between impaired devaluation performance and impaired explicit contingency knowledge. Furthermore, deficits in devaluation performance have been found with a wide range of 'cognitive load' manipulations and psychiatric symptom states, suggesting a general effect produced by task disengagement. Finally, only the minority of studies using two-stage tasks supported habit theory, and these could also be explained by task disengagement. Collectively the studies provide minimal evidence for a specific propensity to habit or impairment in goal-directed control as a major factor controlling human addiction.

The evidence for compulsion theory is also weak. In animals, the primary index of compulsivity-persistence of punished drug seeking in vulnerable animals - is most often associated with greater drug value indexed in a separate assay. The implication is that persistence of punished drug seeking is not due to insensitivity to costs imposed on drug seeking (compulsivity), but due to excessive value of the drug. Human studies have similarly found minimal evidence that dependence is associated with cost discounting in economic demand tasks, reversal learning tasks or concurrent choice tasks where costs are imposed on the drug choice.

The overall conclusion from this translational analysis is that addiction is primarily driven by excessive goal-directed drug choice under negative affect, and much less by habit or compulsion. This conclusion accords with other negative reinforcement models of addiction $[3,9,248]$, except that in the current model, negative states enhance the expected value of the drug driving goal-directed drug choice [10, 11, 74], rather than priming drug seeking automatically as is commonly claimed [9]. Addiction is pathological not because it is automatic, but because negative states powerfully drive up expected drug value acutely outweighing other goals such as a job, abstinence, family and health, resulting in a return to drug use despite wishes to the contrary expressed at other times.

\section{FUNDING AND DISCLOSURE}

The authors declare that they do not have any conflicts of interest (financial or otherwise) related to the content of the paper. The research was supported by an Alcohol Change grant (RS17/03) and a Medical Research Council (UK, MRC) Confidence in Global Mental Health pump priming award (MC_PC_MR/R019991/1) to LH. Funders had no role in the study design, collection, analysis or interpretation of the data, writing the manuscript, or the decision to submit the paper for publication

\section{ADDITIONAL INFORMATION}

Supplementary information accompanies this paper at (https://doi.org/10.1038/ s41386-020-0600-8).

Publisher's note Springer Nature remains neutral with regard to jurisdictional claims in published maps and institutional affiliations.

\section{REFERENCES}

1. Badiani A, Belin D, Epstein D, Calu D, Shaham Y. Opiate versus psychostimulant addiction: the differences do matter. Nat Rev Neurosci. 2011;12:685-700.

2. Wikler A. Conditioning factors in opiate addiction and relapse. J Subst Abus Treat. 1984;1:279-85.

3. Solomon RL, Corbit JD. An opponent-process theory of motivation: II. Cigarette addiction. J Abnorm Psychol. 1973;81:158-71.

4. Siegel S. Pharmacological conditioning and drug effects. In: Goudie A, EmmettOglesby M, editors. Psychoactive drugs tolerance and sensitisation. Clifton, New Jersey: Humana Press; 1989. p. $115-80$. 
5. Khantzian EJ. The self-medication hypothesis of substance use disorders: a reconsideration and recent applications. Harv Rev Psychiatry. 1997;4:231-44.

6. Aguirre C, Madrid J, Leventhal AM. Tobacco withdrawal symptoms mediate motivation to reinstate smoking during abstinence. J Abnorm Psychol. 2015;124:623-34.

7. Hogarth L, Mathew AR, Hitsman B. Current major depression is associated with greater sensitivity to the motivational effect of both negative mood induction and abstinence on tobacco-seeking behavior. Drug Alcohol Depend. 2017;176:1-6.

8. Mathew AR, Hogarth L, Leventhal AM, Cook JW, Hitsman B. Cigarette smoking and depression comorbidity: systematic review and proposed theoretical model. Addiction 2017;112:401-12.

9. Baker TB, Piper ME, McCarthy DE, Majeskie MR, Fiore MC. Addiction motivation reformulated: an affective processing model of negative reinforcement. Psychol Rev. 2004;111:33-51.

10. Hogarth L, Hardy L. Depressive statements prime goal-directed alcohol-seeking in individuals who report drinking to cope with negative affect. Psychopharmacology. 2018;235:269-79.

11. Hogarth L, He Z, Chase HW, Wills AJ, Troisi J II, Leventhal AM, et al. Negative mood reverses devaluation of goal-directed drug-seeking favouring an incentive learning account of drug dependence. Psychopharmacology. 2015;232:3235-47.

12. Wise RA, Koob GF. The development and maintenance of drug addiction. Neuropsychopharmacology. 2014;39:254-62

13. Stewart J, de Wit H, Eikelboom R. Role of conditioned and unconditioned drug effects in self-administration of opiates and stimulants. Psychol Rev. 1984;63:251-68.

14. Higgins ST, Bickel WK, Hughes JR. Influence of an alternative reinforcer on human cocaine self-administration. Life Sci. 1994;55:179-87.

15. Hardy L, Parker S, Hartley L, Hogarth L. A concurrent pictorial drug choice task marks multiple risk factors in treatment-engaged smokers and drinkers. Behav Pharmacol. 2018;29:716-25.

16. Heyman GM, Mims V. What addicts can teach us about addiction: a natural history approach. Addiction and choice. Oxford: Oxford University Press; 2016.

17. Carter BL, Tiffany ST. Meta-analysis of cue-reactivity in addiction research. Addiction. 1999;94:327-40.

18. Tomie A. Locating reward cue at response manipulandum (CAM) induces symptoms of drug abuse. Neurosci Biobehav Rev. 1996;20:505-35.

19. Bindra D. How adaptive behaviour is produced: a perceptual-motivational alternative to response reinforcement. Behavioural Brain Sci. 1978;1:41-91.

20. Robinson $T E$, Berridge $K C$. The neural basis of drug craving: an incentivesensitization theory of drug addiction. Brain Res Rev. 1993;18:247-91.

21. Wiers RW, Boelema SR, Nikolaou K, Gladwin TE. On the development of implicit and control processes in relation to substance use in adolescence. Curr Addiction Rep. 2015;2:141-55.

22. Seabrooke T, Hogarth $\mathrm{L}$, Mitchell CJ. The propositional basis of cue-controlled reward seeking. Q J Exp Psychol. 2016;69:2452-70.

23. Hogarth L, Retzler C, Munafò MR, Tran DMD, Troisi li Jr, Rose AK, et al. Extinction of cue-evoked drug-seeking relies on degrading hierarchical instrumental expectancies. Behav Res Ther. 2014;59:61-70.

24. Perkins KA. Subjective reactivity to smoking cues as a predictor of quitting success. Nicotine Tob Res. 2012;14:383-87.

25. Perkins KA. Does smoking cue-induced craving tell us anything important about nicotine dependence? Addiction. 2009;104:1610-16.

26. Hardy L, Mitchell C, Seabrooke T, Hogarth L. Drug cue reactivity involves hierarchical instrumental learning: evidence from a biconditional Pavlovian to instrumental transfer task. Psychopharmacology. 2017;234:1977-84.

27. Field M, Werthmann J, Franken I, Hofmann W, Hogarth L, Roefs A. The role of attentional bias in obesity and addiction. Health Psychol. 2016;35:767-80.

28. Piazza PV, Deroche-Gamonet V. A multistep general theory of transition to addiction. Psychopharmacol (Berl). 2013;229:387-413.

29. Tiffany ST. A cognitive model of drug urges and drug-use behaviour: role of automatic and nonautomatic processes. Psychol Rev. 1990;97:147-68.

30. Dickinson A, Wood N, Smith JW. Alcohol seeking by rats: action or habit? Q J Exp Psychol B. 2002;55:331-48.

31. Everitt BJ, Robbins TW. Neural systems of reinforcement for drug addiction: from actions to habits to compulsion. Nat Neurosci. 2005;8:1481-9.

32. Everitt BJ, Robbins TW. Drug addiction: updating actions to habits to compulsions ten years on. Annu Rev Psychol. 2016;67:23-50.

33. Verdejo-García A, Alcázar-Córcoles MA, Albein-Urios N. Neuropsychological interventions for decision-making in addiction: a systematic review. Neuropsychol Rev. 2019;29:79-92.

34. Volkow ND, Fowler JS, Wang GJ. The addicted human brain viewed in the light of imaging studies: brain circuits and treatment strategies. Neuropharmacology. 2004;47:3-13.
35. Ersche KD, Roiser JP, Robbins TW, Sahakian BJ. Chronic cocaine but not chronic amphetamine use is associated with perseverative responding in humans. Psychopharmacology. 2008;197:421-31.

36. Bickel WK, Johnson MW, Koffarnus MN, MacKillop J, Murphy JG. The behavioral economics of substance use disorders: reinforcement pathologies and their repair. Ann Rev Clin Psych. 2014;10:641-77.

37. Rochat L, Maurage $P$, Heeren A, Billieux J. Let's open the decision-making umbrella: a framework for conceptualizing and assessing features of impaired decision making in addiction. Neuropsychol Rev. 2019;29:27-51.

38. Wills TA, Simons JS, Sussman S, Knight R. Emotional self-control and dysregulation: a dual-process analysis of pathways to externalizing/internalizing symptomatology and positive well-being in younger adolescents. Drug Alcohol Depend. 2016;163:S37-S45.

39. Hussong AM, Jones DJ, Stein GL, Baucom DH, Boeding S. An internalizing pathway to alcohol use and disorder. Psychol Addictive Behav. 2011;25:390-404.

40. Sussman $S$, Leventhal $A$, Bluthenthal RN, Freimuth $M$, Forster $M$, Ames SL. A framework for the specificity of addictions. Int J Env Res Public Health. 2011;8:3399-415.

41. Corbit LH, Balleine BW. Instrumental and Pavlovian incentive processes have dissociable effects on components of a heterogeneous instrumental chain. J Exp Psychol Anim Behav Process. 2003;29:99-106.

42. Di Ciano P, Everitt BJ. Differential control over drug-seeking behavior by drugassociated conditioned reinforcers and discriminative stimuli predictive of drug availability. Behav Neurosci. 2003;117:952-60.

43. Kearns DN, Kim JS, Tunstall BJ, Silberberg A. Essential values of cocaine and nondrug alternatives predict the choice between them. Addict Biol. 2017;22: 1501-14.

44. Ahmed SH. Validation crisis in animal models of drug addiction: beyond nondisordered drug use toward drug addiction. Neurosci Biobehav Rev. 2010;35:172-84.

45. Panlilio LV, Hogarth L, Shoaib M. Concurrent access to nicotine and sucrose in rats. Psychopharmacology . 2015;232:1451-60.

46. Lenoir M, Augier E, Vouillac C, Ahmed SH. A choice-based screening method for compulsive drug users in rats. Current protocols in neuroscience. John Wiley \& Sons, Inc.; 2013.

47. Lenoir M, Cantin L, Vanhille N, Serre F, Ahmed SH. Extended heroin access increases heroin choices over a potent nondrug alternative. Neuropsychopharmacology. 2013;38:1209-20.

48. Russo M, Funk D, Loughlin A, Coen K, Lê AD. Effects of alcohol dependence on discrete choice between alcohol and saccharin. Neuropsychopharmacology. 2018:43:1859-66.

49. Campbell UC, Carroll ME. Reduction of drug self-administration by an alternative non-drug reinforcer in rhesus monkeys: magnitude and temporal effects. Psychopharmacology. 2000;147:418-25.

50. Woolverton WL, Anderson KG. Effects of delay to reinforcement on the choice between cocaine and food in rhesus monkeys. Psychopharmacology. 2006;186:99-106.

51. Carroll ME, Lac ST, Nygaard SL. A concurrently available nondrug reinforcer prevents the acquisition or decreases the maintenance of cocaine-reinforced behavior. Psychopharmacology. 1989;97:23-29.

52. Carroll ME, Lac ST. Autoshaping i.v. cocaine self-administration in rats: effects of nondrug alternative reinforcers on acquisition. Psychopharmacology. 1993;110:5-12.

53. Ginsburg BC, Lamb RJ. Frustration stress (unexpected loss of alternative reinforcement) increases opioid self-administration in a model of recovery. Drug Alcohol Depend. 2018;182:33-39.

54. LeSage MG. Toward a nonhuman model of contingency management: effects of reinforcing abstinence from nicotine self-administration in rats with an alternative nondrug reinforcer. Psychopharmacology. 2009;203:13-22.

55. Nader MA, Woolverton WL. Choice between cocaine and food by rhesus monkeys: effects of conditions of food availability. Behavioural Pharmacol. 1992;3:635-38

56. Nader MA, Woolverton WL. Effects of increasing response requirement on choice between cocaine and food in rhesus monkeys. Psychopharmacology. 1992;108:295-300.

57. Nader MA, Woolverton WL. Effects of increasing the magnitude of an alternative reinforcer on drug choice in a discrete-trials choice procedure. Psychopharmacology. 1991;105:169-74.

58. Negus SS. Rapid assessment of choice between cocaine and food in rhesus monkeys: effects of environmental manipulations and treatment with $d$ amphetamine and flupenthixol. Neuropsychopharmacology. 2003;28:919.

59. Ito $\mathrm{M}$, Nakamura K. Humans' choice in a self-control choice situation: sensitivity to reinforcer amount, reinforcer delay, and overall reinforcement density. J Exp Anal Behav. 1998;69:87-102. 
60. Venniro M, Zhang M, Caprioli D, Hoots JK, Golden SA, Heins C, et al. Volitional social interaction prevents drug addiction in rat models. Nat Neurosci. 2018;21:1520-29.

61. Venniro M, Caprioli D, Shaham Y. Novel models of drug relapse and craving after voluntary abstinence. Neuropsychopharmacology. 2019;44:234-35.

62. Guillem K, Brenot V, Durand A, Ahmed SH. Neuronal representation of individual heroin choices in the orbitofrontal cortex. Addict Biol. 2017;23:880-888.

63. Guillem K, Ahmed SH. Preference for cocaine is represented in the orbitofrontal cortex by an increased proportion of cocaine use-coding neurons. Cereb Cortex. 2017;28:819-32.

64. Wallis JD. Neuronal mechanisms in prefrontal cortex underlying adaptive choice behavior. Linking affect to action: critical contributions of the orbitofrontal cortex. Oxford: Blackwell Publishing; 2007. p. 447-60.

65. Balleine BW, O'Doherty JP. Human and rodent homologies in action control: corticostriatal determinants of goal-directed and habitual action. Neuropsychopharmacology. 2010;35:48-69.

66. Valentin V, Dickinson A, O'Doherty JP. Determining the neural substrates of goal-directed learning in the human brain. J Neurosci. 2007;27:4019-26.

67. Dickinson A, Balleine BW. The cognitive/motivational interface. In: Kringelbach $\mathrm{ML}$, Berridge KC, editors. Pleasures of the brain. The neural basis of taste, smell and other rewards. Oxford: Oxford University Press; 2010. p. 74-84.

68. Olmstead MC, Lafond MV, Everitt BJ, Dickinson A. Cocaine seeking by rats is a goal-directed action. Behav Neurosci. 2001;115:394-402.

69. Corbit $\mathrm{LH}$, Nie $\mathrm{H}$, Janak PH. Habitual alcohol seeking: time course and the contribution of subregions of the dorsal striatum. Biol Psychiatry. 2012;72:389-95

70. Zapata A, Minney VL, Shippenberg TS. Shift from goal-directed to habitual cocaine seeking after prolonged experience in rats. J Neurosci. 2010;30:15457-63.

71. Clemens KJ, Castino MR, Cornish JL, Goodchild AK, Holmes NM. Behavioral and neural substrates of habit formation in rats intravenously self-administering nicotine. Neuropsychopharmacology. 2014;39:2584-93.

72. Vandaele Y, Vouillac-Mendoza C, Ahmed SH. Inflexible habitual decision-making during choice between cocaine and a nondrug alternative. Transl Psychiatry. 2019;9:109.

73. Halbout B, Liu AT, Ostlund SB. A closer look at the effects of repeated cocaine exposure on adaptive decision-making under conditions that promote goaldirected control. Front Psychiatry. 2016;7:44.

74. Hutcheson DM, Everitt BJ, Robbins TW, Dickinson A. The role of withdrawal in heroin addiction: enhances reward or promotes avoidance? Nat Neurosci. 2001;4:943-47.

75. Kenny PJ, Chen SA, Kitamura O, Markou A, Koob GF. Conditioned withdrawal drives heroin consumption and decreases reward sensitivity. J Neurosci. 2006:26:5894-900

76. Shaham Y, Rajabi H, Stewart J. Relapse to heroin-seeking in rats under opioid maintenance: the effects of stress, heroin priming, and withdrawal. J Neurosci. 1996;16:1957.

77. Negus SS, Banks ML. Modulation of drug choice by extended drug access and withdrawal in rhesus monkeys: implications for negative reinforcement as a driver of addiction and target for medications development. Pharm Biochem Behav. 2018;164:32-39.

78. Carmack SA, Keeley RJ, Vendruscolo JCM, Lowery-Gionta EG, Lu H, Koob GF, et al. Heroin addiction engages negative emotional learning brain circuits in rats. J Clin Investig. 2019;129:2480-84.

79. Spragg SDS. Morphine addiction in chimpanzees. Comp Psychol Monogr. 1940;15:132-32.

80. Negus SS. Choice between heroin and food in nondependent and heroindependent rhesus monkeys: effects of naloxone, buprenorphine, and methadone. J Pharm Exp Ther. 2006;317:711-23.

81. Shaham Y, Stewart J. Stress reinstates heroin-seeking in drug-free animals: an effect mimicking heroin, not withdrawal. Psychopharmacol (Berl). 1995;119:334-41.

82. Goldberg SR, Woods JH, Schuster CR. Morphine: conditioned increases in selfadministration in rhesus monkeys. Science. 1969;166:1306-07.

83. Mantsch JR, Baker DA, Funk D, Le AD, Shaham Y. Stress-induced reinstatement of drug seeking: 20 years of progress. Neuropsychopharmacology. 2016;41:335-56

84. Spanagel R, Noori HR, Heilig M. Stress and alcohol interactions: animal studies and clinical significance. Trends Neurosci. 2014;37:219-27.

85. Sommer WH, Rimondini R, Hansson AC, Hipskind PA, Gehlert DR, Barr CS, et al. Upregulation of voluntary alcohol intake, behavioral sensitivity to stress, and amygdala crhr1 expression following a history of dependence. Biol Psychiatry. 2008;63:139-45.

86. Mantsch JR, Baker DA, Francis DM, Katz ES, Hoks MA, Serge JP. Stressor- and corticotropin releasing factor-induced reinstatement and active stress-related behavioral responses are augmented following long-access cocaine selfadministration by rats. Psychopharmacology. 2008;195:591-603.

87. Ahmed SH, Walker JR, Koob GF. Persistent increase in the motivation to take heroin in rats with a history of drug escalation. Neuropsychopharmacology. 2000;22:413-21.

88. Blacktop JM, Seubert C, Baker DA, Ferda N, Lee G, Graf EN, et al. Augmented cocaine seeking in response to stress or CRF delivered into the ventral tegmental area following long-access self-administration is mediated by CRF receptor type 1 but not CRF receptor type 2. J Neurosci. 2011;31:11396.

89. Siegmund S, Vengeliene V, Singer MV, Spanagel R. Influence of age at drinking onset on long-term ethanol self-administration with deprivation and stress phases. Alcohol Clin Exp Res. 2005;29:1139-45.

90. Fullgrabe MW, Vengeliene $V$, Spanagel R. Influence of age at drinking onset on the alcohol deprivation effect and stress-induced drinking in female rats. Pharm Biochem Behav. 2007:86:320-6.

91. Feltenstein MW, Henderson AR, See RE. Enhancement of cue-induced reinstatement of cocaine-seeking in rats by yohimbine: sex differences and the role of the estrous cycle. Psychopharmacology (Berlin). 2011;216:53-62.

92. Buffalari DM, Baldwin CK, Feltenstein MW, See RE. Corticotrophin releasing factor (CRF) induced reinstatement of cocaine seeking in male and female rats. Physiol Behav. 2012;105:209-14.

93. Shalev U, Morales M, Hope B, Yap J, Shaham Y. Time-dependent changes in extinction behavior and stress-induced reinstatement of drug seeking following withdrawal from heroin in rats. Psychopharmacology. 2001;156:98-107.

94. Erb S. Evaluation of the relationship between anxiety during withdrawal and stress-induced reinstatement of cocaine seeking. Prog Neuropsychopharmacol Biol Psychiatry. 2010;34:798-807.

95. Heilig M, Egli M, Crabbe JC, Becker HC. Acute withdrawal, protracted abstinence and negative affect in alcoholism: are they linked? Addict Biol. 2010;15:169-84.

96. Schwabe L, Dickinson A, Wolf OT. Stress, habits and drug addiction: a psychoneuroendocrinological perspective. Exp Clin Psychopharmacol. 2011;19:53-63.

97. Girardeau P, Navailles S, Durand A, Vouillac-Mendoza C, Guillem K, Ahmed SH. Relapse to cocaine use persists following extinction of drug-primed craving. Neuropharmacology. 2019;155:185-93.

98. Murphy JG, Mackillop J. Relative reinforcing efficacy of alcohol among college student drinkers. Exp Clin Psychopharmacol. 2006;14:219-27.

99. MacKillop J, Murphy JG. A behavioral economic measure of demand for alcohol predicts brief intervention outcomes. Drug Alcohol Depend. 2007;89:227-33.

100. Murphy JG, MacKillop J, Skidmore JR, Pederson AA. Reliability and validity of a demand curve measure of alcohol reinforcement. Exp Clin Psychopharmacol 2009;17:396-404.

101. Petry NM. A behavioral economic analysis of polydrug abuse in alcoholics: asymmetrical substitution of alcohol and cocaine. Drug Alcohol Depend. 2001:62:31-9.

102. MacKillop J, Tidey JW. Cigarette demand and delayed reward discounting in nicotine dependent individuals with schizophrenia and controls: an initial study. Psychopharmacology. 2011;216:91-99.

103. Bruner NR, Johnson MW. Demand curves for hypothetical cocaine in cocainedependent individuals. Psychopharmacology. 2014;231:889-97.

104. Murphy JG, Correia CJ, Colby SM, Vuchinich RE. Using behavioral theories of choice to predict drinking outcomes following a brief intervention. Exp Clin Psychopharmacol. 2005;13:93-101.

105. Amlung MT, Acker J, Stojek MK, Murphy JG, MacKillop J. Is talk "cheap"? An initial investigation of the equivalence of alcohol purchase task performance for hypothetical and actual rewards. Alcohol, Clin Exp Res. 2012;36:716-24.

106. Madden GJ, Bickel WK. Abstinence and price effects on demand for cigarettes: a behavioral-economic analysis. Addiction. 1999;94:577-88.

107. Mackillop J, Brown CL, Stojek MK, Murphy CM, Sweet L, Niaura RS. Behavioral economic analysis of withdrawal- and cue-elicited craving for tobacco: an initial investigation. Nicotine Tob Res. 2012;14:1426-34.

108. Owens MM, Ray LA, MacKillop J. Behavioral economic analysis of stress effects on acute motivation for alcohol. J Exp Anal Behav. 2015;103:77-86.

109. Gray JC, MacKillop J. Interrelationships among individual differences in alcohol demand, impulsivity, and alcohol misuse. Psychol Addict Behav. 2014;28:282-7.

110. Murphy JG, Yurasek AM, Dennhardt AA, Skidmore JR, McDevitt-Murphy ME, MacKillop J, et al. Symptoms of depression and PTSD are associated with elevated alcohol demand. Drug Alcohol Depend. 2013;127:129-36.

111. Hogarth L, Chase HW. Parallel goal-directed and habitual control of human drug-seeking: implications for dependence vulnerability. J Exp Psychol: Anim Behav Process. 2011;37:261-76.

112. Hogarth L, Hardy L. Alcohol dependence symptoms are associated with greater relative value ascribed to alcohol, but not greater discounting of costs imposed on alcohol. Psychopharmacology. 2018;235:2257-66.

113. Hardy L, Hogarth L. A novel concurrent pictorial choice model of mood-induced relapse in hazardous drinkers. Exp Clin Psychopharmacol. 2017;25:448-55. 
114. Miele A, Thompson M, Jao NC, Kalhan R, Leone F, Hogarth L, et al. Cancer patients enrolled in a smoking cessation clinical trial: characteristics and correlates of smoking rate and nicotine dependence. J Addiction. 2018;2018:7.

115. Hogarth L, Hardy L, Mathew AR, Hitsman B. Negative mood-induced alcoholseeking is greater in young adults who report depression symptoms, drinking to cope, and subjective reactivity. Exp Clin Psychopharmacol. 2018;26:138-46.

116. Moeller SJ, Beebe-Wang N, Woicik PA, Konova AB, Maloney T, Goldstein RZ. Choice to view cocaine images predicts concurrent and prospective drug use in cocaine addiction. Drug Alcohol Depend. 2013;130:178-85.

117. Moeller SJ, Maloney T, Parvaz MA, Dunning JP, Alia-Klein N, Woicik PA, et al. Enhanced choice for viewing cocaine pictures in cocaine addiction. Biol Psychiatry. 2009;66:169-76.

118. Bickel WK, DeGrandpre RJ, Higgins ST, Hughes JR, Badger GJ. Effects of simulated employment and recreation on drug taking: a behavioral economic analysis. Exp Clin Psychopharmacol. 1995;3:467-76.

119. Hart CL, Haney M, Foltin RW, Fischman MW. Alternative reinforcers differentially modify cocaine self-administration by humans. Behav Pharmacol. 2000;11:87-91.

120. Stoops WW, Lile JA, Glaser PEA, Hays LR, Rush CR. Alternative reinforcer response cost impacts cocaine choice in humans. Prog Neuro-Psychopharmacol Biol Psychiatry. 2012;36:189-93.

121. Hatsukami DK, Thompson TN, Pentel PR, Flygare BK, Carroll ME. Selfadministration of smoked cocaine. Exp Clin Psychopharmacol. 1994;2:115-25.

122. Lile JA, Stoops WW, Rush CR, Negus SS, Glaser PEA, Hatton KW, et al. Development of a translational model to screen medications for cocaine use disorder II: choice between intravenous cocaine and money in humans. Drug Alcohol Depend. 2016;165:111-19.

123. Comer SD, Metz VE, Cooper ZD, Kowalczyk WJ, Jones JD, Sullivan MA, et al. Comparison of a drug versus money and drug versus drug self-administration choice procedure with oxycodone and morphine in opioid addicts. Behav Pharmacol. 2013;24:504-16.

124. Cassidy RN, Tidey JW, Kahler CW, Wray TB, Colby SM. Increasing the value of an alternative monetary reinforcer reduces cigarette choice in adolescents. Nicotine Tob Res. 2015;17:1449-55.

125. Hogarth L, Hardy L, Bakou AE, Mahlberg J, Weidemann G, Cashel S, et al. Negative mood induction increases choice of heroin versus food pictures in opiate dependent individuals: correlation with self-medication coping motives and subjective reactivity. Front Psychiatry. 2019;10:274. in press

126. Moeller SJ, Zilverstand A, Konova AB, Kundu P, Parvaz MA, Preston-Campbell R, et al. Neural correlates of drug-biased choice in currently using and abstinent individuals with cocaine use disorder. Biol Psychiatry. 2017;3:485-94. in press

127. Moeller SJ, Maloney T, Parvaz MA, Alia-Klein N, Woicik PA, Telang F, et al. Impaired insight in cocaine addiction: laboratory evidence and effects on cocaine-seeking behaviour. Brain. 2010;133:1484-93.

128. Chase HW, MacKillop J, Hogarth L. Isolating behavioural economic indices of demand in relation to nicotine dependence. Psychopharmacology. 2013;226: 371-80.

129. Perkins KA, Broge M, Gerlach D, Sanders M, Grobe JE, Cherry C, et al. Acute nicotine reinforcement, but not chronic tolerance, predicts withdrawal and relapse after quitting smoking. Health Psychol. 2002;21:332-39.

130. Hogarth L. Goal-directed and transfer-cue-elicited drug-seeking are dissociated by pharmacotherapy: evidence for independent additive controllers. J Exp Psychol: Anim Behav Processes. 2012;38:266-78.

131. Johnson MW, Bickel WK. The behavioral economics of cigarette smoking: the concurrent presence of a substitute and an independent reinforcer. Behav Pharmacol. 2003;14:137-44.

132. Higgins ST, Roll JM, Bickel WK. Alcohol pretreatment increases preference for cocaine over monetary reinforcement. Psychopharmacology. 1996;123:1-8.

133. Vuchinich RE, Tucker JA. Behavioral theories of choice as a framework for studying drinking behaviour. J Abnorm Psychol. 1983;92:408-16.

134. Vuchinich RE, Tucker JA, Rudd EJ. Preference for alcohol consumption as a function of amount and delay of alternative reward. J Abnorm Psychol. 1987;96:259-63.

135. Hogarth L, Field M, Rose AK. Phasic transition from goal-directed to habitual control over drug-seeking produced by conflicting reinforcer expectancy. Addict Biol. 2013;18:88-97.

136. Brady KT, Back SE, Waldrop AE, McRae AL, Anton RF, Upadhyaya HP, et al. Cold pressor task reactivity: predictors of alcohol use among alcohol-dependent individuals with and without comorbid posttraumatic stress disorder. Alcohol: Clin Exp Res. 2006;30:938-46.

137. Cooney NL, Litt MD, Morse PA, Bauer LO, Gaupp L. Alcohol cue reactivity, negative-mood reactivity, and relapse in treated alcoholic men. J Abnorm Psychol. 1997;106:243-50

138. Higley A, Crane N, Spadoni A, Quello S, Goodell V, Mason B. Craving in response to stress induction in a human laboratory paradigm predicts treatment outcome in alcohol-dependent individuals. Psychopharmacology. 2011;218:121-29.
139. Sinha R, Fox HC, Hong K, Hansen J, Tuit K, Kreek M. Effects of adrenal sensitivity, stress- and cue-induced craving, and anxiety on subsequent alcohol relapse and treatment outcomes. Arch Gen Psychiatry. 2011;68:942-52.

140. Sinha R, Garcia M, Paliwal P, Kreek M, Rounsaville BJ. Stress-induced cocaine craving and hypothalamic-pituitary-adrenal responses are predictive of cocaine relapse outcomes. Arch Gen Psychiatry. 2006;63:324-31.

141. Back SE, Hartwell K, DeSantis SM, Saladin M, McRae-Clark AL, Price KL, et al. Reactivity to laboratory stress provocation predicts relapse to cocaine. Drug Alcohol Depend. 2010;106:21-27.

142. Rousseau GS, Irons JG, Correia CJ. The reinforcing value of alcohol in a drinking to cope paradigm. Drug Alcohol Depend. 2011;118:1-4.

143. Field M, Quigley M. Mild stress increases attentional bias in social drinkers who drink to cope: a replication and extension. Exp Clin Psychopharmacol. 2009;17:312-19.

144. Birch CD, Stewart SH, Wall A, McKee SA, Eisnor SJ, Theakston JA. Mood-induced increases in alcohol expectancy strength in internally motivated drinkers. Psychol Addictive Behav. 2004;18:231-38.

145. Grant VV, Stewart SH, Birch CD. Impact of positive and anxious mood on implicit alcohol-related cognitions in internally motivated undergraduate drinkers. Addict Behav. 2007:32:2226-37.

146. Field $M$, Powell $H$. Stress increases attentional bias for alcohol cues in social drinkers who drink to cope. Alcohol Alcohol. 2007;42:560-66.

147. Zack M, Poulos CX, Fragopoulos F, MacLeod CM. Effects of negative and positive mood phrases on priming of alcohol words in young drinkers with high and low anxiety sensitivity. Exp Clin Psychopharmacol. 2003;11:176-85.

148. Austin JL, Smith JE. Drinking for negative reinforcement: the semantic priming of alcohol concepts. Addict Behav. 2008;33:1572-80.

149. Woud ML, Becker ES, Rinck $M$, Salemink $E$. The relationship between drinking motives and alcohol-related interpretation biases. J Behav Ther Exp Psychiatry. 2015;47:102-10.

150. Fucito LM, Juliano LM. Depression moderates smoking behavior in response to a sad mood induction. Psychol Addictive Behav. 2009;23:546-51.

151. Sinha R, Fox HC, Hong KA, Bergquist K, Bhagwagar Z, Siedlarz KM. Enhanced negative emotion and alcohol craving, and altered physiological responses following stress and cue exposure in alcohol dependent individuals. Neuropsychopharmacology. 2009;34:1198-208.

152. Zack M, Poulos CX, Fragopoulos F, Woodford TM, MacLeod CM. Negative affect words prime beer consumption in young drinkers. Addict Behav. 2006;31: 169-73.

153. Randall DM, Cox WM. Experimental mood inductions in persons at high and low risk for alcohol problems. Am J Drug Alcohol Abus. 2001;27:183-87.

154. Zack M, Toneatto T, MacLeod CM. Implicit activation of alcohol concepts by negative affective cues distinguishes between problem drinkers with high and low psychiatric distress. J Abnorm Psychol. 1999;108:518-31.

155. Boschloo L, Vogelzangs N, van den Brink W, Smit JH, Veltman DJ, Beekman AT, et al. Depressive and anxiety disorders predicting first incidence of alcohol use disorders: results of the Netherlands Study of Depression and Anxiety (NESDA). J Clin Psychiatry. 2013;74:1233-40.

156. Kushner MG, Abrams K, Thuras P, Hanson KL, Brekke M, Sletten S. Follow-up study of anxiety disorder and alcohol dependence in comorbid alcoholism treatment patients. Alcohol: Clin Exp Res. 2005;29:1432-43.

157. Bruce SE, Yonkers KA, Otto MW, Eisen JL, Weisberg RB, Pagano M, et al. Influence of psychiatric comorbidity on recovery and recurrence in generalized anxiety disorder, social phobia, and panic disorder: a 12-year prospective study. Am J Psychiatry. 2005;162:1179-87.

158. King SM, lacono WG, McGue M. Childhood externalizing and internalizing psychopathology in the prediction of early substance use. Addiction. 2004;99:1548-59.

159. Zimmermann $P$, Wittchen HU, Höfler $M$, Pfister $H$, Kessler RC, Lieb R. Primary anxiety disorders and the development of subsequent alcohol use disorders: a 4-year community study of adolescents and young adults. Psychol Med. 2003:33:1211-22.

160. Samet S, Fenton MC, Nunes E, Greenstein E, Aharonovich E, Hasin D. Effects of independent and substance-induced major depressive disorder on remission and relapse of alcohol, cocaine and heroin dependence. Addiction (Abingdon, Engl). 2013;108:115-23.

161. Sihvola E, Rose RJ, Dick DM, Pulkkinen L, Marttunen M, Kaprio J. Early-onset depressive disorders predict the use of addictive substances in adolescence: a prospective study of adolescent Finnish twins. Addiction. 2008;103:2045-53.

162. Crum RM, Pratt LA. Risk of heavy drinking and alcohol use disorders in social phobia: a prospective analysis. Am J Psychiatry. 2001;158:1693-700.

163. Crum RM, Mojtabai R, Lazareck S, Bolton JM, Robinson J, Sareen J, et al. A prospective assessment of reports of drinking to self-medicate mood symptoms with the incidence and persistence of alcohol dependence. JAMA Psychiatry. 2013;70:718-26. 
164. Crum RM, La Flair L, Storr CL, Green KM, Stuart EA, Alvanzo AAH, et al. Reports of drinking to self-medicate anxiety symptoms: longitudinal assessment for subgroups of individuals with alcohol dependence. Depress Anxiety. 2013;30:174-83.

165. Crum RM, Green KM, Storr CL, Chan YF, lalongo N, Stuart EA, et al. Depressed mood in childhood and subsequent alcohol use through adolescence and young adulthood. Arch Gen Psychiatry. 2008;65:702-12.

166. Gilman SE, Abraham HD. A longitudinal study of the order of onset of alcohol dependence and major depression. Drug Alcohol Depend. 2001;63:277-86.

167. Holahan CJ, Moos RH, Holahan CK, Cronkite RC, Randall PK. Drinking to cope, emotional distress and alcohol use and abuse: a ten-year model. J Stud Alcohol. 2001;62:190-98.

168. Vernig PM, Orsillo SM. Drinking motives and college alcohol problems: a prospective study. J Subst Use. 2015;20:340-46.

169. Hussong AM, Ennett ST, Cox MJ, Haroon M. A systematic review of the unique prospective association of negative affect symptoms and adolescent substance use controlling for externalizing symptoms. Psychol Addictive Behav. 2017;31:137-47.

170. Simpson TL, Miller WR. Concomitance between childhood sexual and physical abuse and substance use problems: a review. Clin Psychol Rev. 2002;22:27-77.

171. Konkolÿ Thege B, Horwood L, Slater L, Tan MC, Hodgins DC, Wild TC. Relationship between interpersonal trauma exposure and addictive behaviors: a systematic review. BMC Psychiatry. 2017;17:164.

172. Butt S, Chou S, Browne K. A rapid systematic review on the association between childhood physical and sexual abuse and illicit drug use among males. Child Abus Rev. 2011;20:6-38.

173. Brady KT, Back SE. Childhood trauma, posttraumatic stress disorder, and alcohol dependence. Alcohol Res: Curr Rev. 2012;34:408-13.

174. Miles FJ, Everitt BJ, Dickinson A. Oral cocaine seeking by rats: action or habit? Behav Neurosci. 2003;117:927-38.

175. Mangieri RA, Cofresí RU, Gonzales RA. Ethanol seeking by long evans rats is not always a goal-directed behavior. PLoS ONE 2012;7:e42886

176. Loughlin A, Funk D, Coen K, Lê AD. Habitual nicotine-seeking in rats following limited training. Psychopharmacology. 2017;234:2619-29.

177. Schmitzer-Torbert N, Apostolidis S, Amoa R, O'Rear C, Kaster M, Stowers J, et al. Post-training cocaine administration facilitates habit learning and requires the infralimbic cortex and dorsolateral striatum. Neurobiol Learn Mem. 2015;118:105-12.

178. Corbit LH, Chieng BC, Balleine BW. Effects of repeated cocaine exposure on habit learning and reversal by $\mathrm{N}$-acetylcysteine. Neuropsychopharmacology. 2014;39:1893-901.

179. Nordquist RE, Voorn P, Malsen J, Joosten R, Pennartz CMA, Vanderschuren L. Augmented reinforcer value and accelerated habit formation after repeated amphetamine treatment. Eur Neuropsychopharmacol. 2007;17:532-40.

180. Nelson AJD, Killcross S. Accelerated habit formation following amphetamine exposure is reversed by D1, but enhanced by D2, receptor antagonists. Front Neurosci. 2013;7:Article76.

181. Nelson A, Killcross S. Amphetamine exposure enhances habit formation. J Neurosci. 2006;26:3805-12.

182. Schoenbaum G, Setlow B. Cocaine makes actions insensitive to outcomes but not extinction: Implications for altered orbitofrontal-amygdalar function. Cereb Cortex. 2005;15:1162-69.

183. LeBlanc KH, Maidment NT, Ostlund SB. Repeated cocaine exposure facilitates the expression of incentive motivation and induces habitual control in rats. PLoS ONE 2013:8:e61355.

184. Son J-H, Latimer C, Keefe KA. Impaired formation of stimulus-response, but not action-outcome, associations in rats with methamphetamine-induced neurotoxicity. Neuropsychopharmacology. 2011;36:2441-51.

185. Shiflett MW. The effects of amphetamine exposure on outcome-selective Pavlovian-instrumental transfer in rats. Psychopharmacology. 2012;223:361-70.

186. Ripley TL, Borlikova G, Lyons S, Stephens DN. Selective deficits in appetitive conditioning as a consequence of ethanol withdrawal. Eur J Neurosci. 2004;19:415-25.

187. Dickinson A, Balleine BW, Watt A, Gonzalez F, Boakes RA. Motivational control after extended instrumental training. Anim Learn Behav. 1995;23:197-206.

188. de Wit S, Kindt M, Knot SL, Verhoeven AAC, Robbins TW, Gasull-Camos J, et al. Shifting the balance between goals and habits: five failures in experimental habit induction. J Exp Psychol Gen. 2018;147:1043-65.

189. Corbit LH, Nie H, Janak PH. Habitual responding for alcohol depends upon both AMPA and D2 receptor signaling in the dorsolateral striatum. Front Behav Neurosci. 2014;8:301.

190. Perez OD, Dickinson A. A theory of actions and habits in free-operant behavior: the interaction of rate correlation and contiguity systems. bioRxiv. 2019:807800.

191. Trask S, Shipman ML, Green JT, Bouton ME. Some factors that restore goaldirection to a habitual behavior. Neurobiol Learn Mem. 2020; in press.
192. Phillips GD, Vugler A. Effects of sensitization on the detection of an instrumental contingency. Pharm Biochem Behav. 2011;100:48-58.

193. Colwill RM, Rescorla RA. Instrumental responding remains sensitive to reinforcer devaluation after extensive training. J Exp Psychol Anim Behav Process. 1985;11:520-36.

194. Colwill RM, Triola SM. Instrumental responding remains under the control of the consequent outcome after extended training. Behav Process. 2002;57:51-64.

195. Holland PC. Relations between Pavlovian-instrumental transfer and reinforcer devaluation. J Exp Psychol Anim Behav Process. 2004;30:258-58.

196. Kosaki Y, Dickinson A. Choice and contingency in the development of behavioral autonomy during instrumental conditioning. J Exp Psychol: Anim Behav Process. 2010;36:334-42.

197. Singer BF, Fadanelli M, Kawa AB, Robinson TE. Are cocaine-seeking "habits" necessary for the development of addiction-like behavior in rats? J Neurosci. 2018;38:60.

198. Heather N. Is the concept of compulsion useful in the explanation or description of addictive behaviour and experience? Addictive Behav Rep. 2017;6:15-38.

199. Hogarth L, Chase HW, Baess K. Impaired goal-directed behavioural control in human impulsivity. Q J Exp Psychol. 2012;65:305-16.

200. Hogarth L, Lam-Cassettari C, Pacitti H, Currah T, Mahlberg J, Hartley L, et al. Intact goal-directed control in treatment-seeking drug users indexed by outcome-devaluation and Pavlovian to instrumental transfer: critique of habit theory. Eur J Neurosci. 2018;50:2513-25.

201. Luijten M, Franken IHA, Gillan CM, De Wit S, Robbins TW, Ersche KD. Goaldirected and habitual control in smokers. Nicotine Tob Res. 2019;15:ntz001.

202. Sjoerds Z, de Wit S, van den Brink W, Robbins TW, Beekman AT, Penninx BW et al. Behavioral and neuroimaging evidence for overreliance on habit learning in alcohol-dependent patients. Transl Psychiatry. 2013;3:e337.

203. Ersche KD, Gillan CM, Jones PS, Williams GB, Ward LHE, Luijten M, et al. Carrots and sticks fail to change behavior in cocaine addiction. Science. 2016:352:1468-71.

204. Mitchell CJ, De Houwer J, Lovibond PF. The propositional nature of human associative learning. Behav Brain Sci. 2009;32:183-98.

205. Lovibond PF. Cognitive processes in extinction. Learn Mem. 2004;11:495-500.

206. Newell BR, Lagnado DA, Shanks DR. Challenging the role of implicit processes in probabilistic category learning. Psychonomic Bull Rev. 2007;14:505-11.

207. Shanks DR, St. John MF. Characteristics of dissociable human learning systems. Behav Brain Sci. 1994;17:367-447.

208. Hogarth L, Duka T. Human nicotine conditioning requires explicit contingency knowledge: is addictive behaviour cognitively mediated? Psychopharmacology. 2006;184:553-66.

209. De Houwer J, Tanaka A, Moors A, Tibboel H. Kicking the habit: why evidence for habits in humans might be overestimated. Motivation. Science. 2018;4:50-59.

210. Potvin S, Stavro K, Rizkallah E, Pelletier J. Cocaine and cognition: a systematic quantitative review. J Addict Med. 2014;8:368-76.

211. Stavro K, Pelletier J, Potvin S. Widespread and sustained cognitive deficits in alcoholism: a meta-analysis. Addict Biol. 2013;18:203-13.

212. Conti AA, McLean L, Tolomeo S, Steele JD, Baldacchino A. Chronic tobacco smoking and neuropsychological impairments: a systematic review and metaanalysis. Neurosci Biobehav Rev. 2019;96:143-54.

213. Gillan CM, Papmeyer M, Morein-Zamir S, Sahakian BJ, Fineberg NA, Robbins TW et al. Disruption in the balance between goal-directed behavior and habit learning in obsessive-compulsive disorder. Am J Psychiatry. 2011;168:718-26.

214. Pritchard T, Weidemann G, Hogarth L. Negative emotional appraisal selectively disrupts retrieval of expected outcome values required for goal-directed instrumental choice. Cognition Emot. 2018;32:843-51.

215. Fournier M, d'Arripe- Longueville F, Radel R. Effects of psychosocial stress on the goal-directed and habit memory systems during learning and later execution. Psychoneuroendocrinology. 2017;77:275-83.

216. Schwabe L, Wolf OT. Stress prompts habit behavior in humans. J Neurosci. 2009;29:7191-98.

217. Schwabe L, Wolf OT. Socially evaluated cold pressor stress after instrumental learning favors habits over goal-directed action. Psychoneuroendocrinology. 2010;35:977-86

218. Schwabe L, Wolf OT. Stress-induced modulation of instrumental behavior: from goal-directed to habitual control of action. Behav Brain Res. 2011;219:321-8.

219. Soares JM, Sampaio A, Ferreira LM, Santos NC, Marques F, Palha JA, et al. Stressinduced changes in human decision-making are reversible. Transl Psychiatry. 2012;2:e131.

220. Hogarth L, Attwood AS, Bate HA, Munafò MR. Acute alcohol impairs human goal-directed action. Biol Psychol. 2012;90:154-60.

221. Furlong TM, Supit AS, Corbit LH, Killcross S, Balleine BW. Pulling habits out of rats: adenosine $2 \mathrm{~A}$ receptor antagonism in dorsomedial striatum rescues methamphetamine-induced deficits in goal-directed action. Addict Biol. 2017;22: $172-83$ 
222. Ostlund SB, Maidment NT, Balleine BW. Alcohol-paired contextual cues produce an immediate and selective loss of goal-directed action in rats. Front Integr Neurosci. 2010;4:19.

223. Chen J, Liang J, Lin X, Zhang Y, Zhang Y, Lu L, et al. Sleep deprivation promotes habitual control over goal-directed control: behavioral and neuroimaging evidence. J Neurosci. 2017;37:11979.

224. Alvares GA, Balleine BW, Guastella AJ. Impairments in goal-directed actions predict treatment response to cognitive-behavioral therapy in social anxiety disorder. PLoS ONE. 2014;9:e94778.

225. Alvares GA, Balleine BW, Whittle L, Guastella AJ. Reduced goal-directed action control in autism spectrum disorder. Autism Res. 2016;9:1285-93.

226. Morris RW, Quail S, Griffiths KR, Green MJ, Balleine BW. Corticostriatal control of goal-directed action is impaired in schizophrenia. Biol Psychiatry. 2015;77:187-95.

227. de Wit S, Barker RA, Dickinson AD, Cools R. Habitual versus goal-directed action control in Parkinson disease. J Cogn Neurosci. 2011;23:1218-29.

228. Klossek UMH, Russell J, Dickinson A. The control of instrumental action following outcome devaluation in young children aged between 1 and 4 years. J Exp Psychol Gen. 2008;137:39-51.

229. Sebold M, Deserno L, Nebe S, Schad DJ, Garbusow M, Hagele C, et al. Modelbased and model-free decisions in alcohol dependence. Neuropsychobiology. 2014;70:122-31.

230. Patzelt EH, Kool W, Millner AJ, Gershman SJ. Incentives boost model-based control across a range of severity on several psychiatric constructs. Biol Psychiatry. 2019;85:425-33.

231. Otto AR, Gershman SJ, Markman AB, Daw ND. The curse of planning: Dissecting multiple reinforcement-learning systems by taxing the central executive. Psychol Sci. 2013;24:751-61.

232. Otto AR, Raio CM, Chiang A, Phelps EA, Daw ND. Working-memory capacity protects model-based learning from stress. Proc Natl Acad Sci USA. 2013;110:201941

233. Reiter AMF, Deserno L, Wilbertz T, Heinze H-J, Schlagenhauf F. Risk factors for addiction and their association with model-based behavioral control. Front Behav Neurosci. 2016;10:26.

234. Schad DJ, Jünger $E$, Sebold $M$, Garbusow $M$, Bernhardt N, Javadi $A-H$, et al. Processing speed enhances model-based over model-free reinforcement learning in the presence of high working memory functioning. Front Psychol. 2014;5:1450-50.

235. MacKillop J, Murphy JG. A behavioral economic measure of demand for alcohol predicts brief intervention outcomes. Drug Alcohol Depend. 2007;89:227-33.

236. Murphy JG, MacKillop J. Relative reinforcing efficacy of alcohol among college student drinkers. Exp Clin Psychopharmacol. 2006;14:219-27.

237. MacKillop J, Miranda R, Monti PM, Ray LA, Murphy JG, Rohsenow DJ, et al. Alcohol demand, delayed reward discounting, and craving in relation to drinking and alcohol use disorders. J Abnorm Psychol. 2010;119:106-14.

238. MacKillop J, Jackson JN, Murphy JG, Amlung MT. Associations between individual differences in alcohol's relative reinforcing value and alcohol misuse: a meta-analysis. Alcoholism: Clinical and Experimental Research. 2015;39.

239. Zvorsky I, Nighbor TD, Kurti AN, DeSarno M, Naudé G, Reed DD, et al. Sensitivity of hypothetical purchase task indices when studying substance use: A systematic literature review. Preventive Med. 2019;128:105789.

240. Gonzalez-Roz A, Jackson J, Murphy C, Rohsenow DJ, MacKillop J. Behavioral economic tobacco demand in relation to cigarette consumption and nicotine dependence: a meta-analysis of cross-sectional relationships. Addiction 2019;114:1926-40.

241. González-Roz A, Secades-Villa R, Weidberg S, García-Pérez Á, Reed DD. Latent structure of the cigarette purchase task among treatment-seeking smokers with depression and its predictive validity on smoking abstinence. Nicotine Tob Res. 2018.

242. Murphy JG, Yurasek AM, Meshesha LZ, Dennhardt AA, Mackillop J, Skidmore JR, et al. Family history of problem drinking is associated with less sensitivity of alcohol demand to a next-day responsibility. J Stud Alcohol Drugs. 2014;75:653-63.

243. Fortier CB, LaFleche G, Disterhoft JF, Steffen EM, Venne JR, McGlinchey RE. Delay discrimination and reversal eyeblink classical conditioning in abstinent chronic alcoholics. Neuropsychology. 2008;22:196-208.

244. Reiter AMF, Deserno L, Kallert T, Heinze H-J, Heinz A, Schlagenhauf F. Behavioral and neural signatures of reduced updating of alternative options in alcoholdependent patients during flexible decision-making. J Neurosci. 2016;36:10935.

245. Vanes LD, van Holst RJ, Jansen JM, van den Brink W, Oosterlaan J, Goudriaan AE. Contingency learning in alcohol dependence and pathological gambling: learning and unlearning reward contingencies. Alcohol: Clin Exp Res. 2014;38:1602-10.

246. Jentsch JD, Olausson P, De La Garza R II, Taylor JR. Impairments of reversal learning and response perseveration after repeated, intermittent cocaine administrations to monkeys. Neuropsychopharmacology. 2002;26:183-90.
247. Lucantonio F, Stalnaker TA, Shaham Y, Niv Y, Schoenbaum G. The impact of orbitofrontal dysfunction on cocaine addiction. Nat Neurosci. 2012;15:358-66.

248. Koob GF. Addiction is a reward deficit and stress surfeit disorder. Front Psychiatry. 2013;4:72

249. Hogarth L, Martin L, Seedat S. Relationship between childhood abuse and substance misuse problems is mediated by substance use coping motives, in school attending South African adolescents. Drug Alcohol Depend. 2019;194:69-74.

250. Stewart SH, Sherry SB, Comeau MN, Mushquash CJ, Collins P, Van Wilgenburg H. Hopelessness and excessive drinking among aboriginal adolescents: the mediating roles of depressive symptoms and drinking to cope. Depression Res Treat. 2011;2011:11.

251. Martin G, Inchley J, Currie C. Do drinking motives mediate the relationship between neighborhood characteristics and alcohol use among adolescents? Int J Env Res Public Health. 2019;16:853.

252. Mohr CD, McCabe CT, Haverly SN, Hammer LB, Carlson KF. Drinking motives and alcohol use: the SERVe study of U.S. Current and former service members. J Stud Alcohol Drugs. 2018;79:79-87.

253. Miller SM, Pedersen ER, Marshall GN. Combat experience and problem drinking in veterans: exploring the roles of PTSD, coping motives, and perceived stigma. Addict Behav. 2017;66:90-95.

254. Øverup CS, DiBello AM, Brunson JA, Acitelli LK, Neighbors C. Drowning the pain: intimate partner violence and drinking to cope prospectively predict problem drinking. Addict Behav. 2015;41:152-61.

255. Vilhena-Churchill N, Goldstein AL. Child maltreatment and marijuana problems in young adults: examining the role of motives and emotion dysregulation. Child Abus Negl. 2014:38:962-72.

256. Chinneck A, Thompson K, Dobson KS, Stuart H, Teehan M, Stewart SH. Neurotic personality traits and risk for adverse alcohol outcomes: chained mediation through emotional disorder symptoms and drinking to cope. Subst Use Misuse. 2018;53:1730-41.

257. Collins JL, Thompson K, Sherry SB, Glowacka M, Stewart SH. Drinking to cope with depression mediates the relationship between social avoidance and alcohol problems: a 3-wave, 18-month longitudinal study. Addict Behav. 2018;76:182-87.

258. Dvorak RD, Pearson MR, Day AM. Ecological momentary assessment of acute alcohol use disorder symptoms: associations with mood, motives, and use on planned drinking days. Exp Clin Psychopharmacol. 2014;22:285-97.

259. Asberg K, Renk K. Substance use coping as a mediator of the relationship between trauma symptoms and substance use consequences among incarcerated females with childhood sexual abuse histories. Subst Use Misuse. 2012;47:799-808.

260. O'Hare T, Sherrer M. Drinking motives as mediators between PTSD symptom severity and alcohol consumption in persons with severe mental illnesses. Addict Behav. 2011;36:465-69.

261. Topper LR, Castellanos-Ryan N, Mackie C, Conrod PJ. Adolescent bullying victimisation and alcohol-related problem behaviour mediated by coping drinking motives over a 12 month period. Addict Behav. 2011;36:6-13.

262. Fossos N, Kaysen D, Neighbors C, Lindgren KP, Hove MC. Coping motives as a mediator of the relationship between sexual coercion and problem drinking in college students. Addict Behav. 2011;36:1001-07.

263. Gonzalez VM, Reynolds B, Skewes MC. Role of impulsivity in the relationship between depression and alcohol problems among emerging adult college drinkers. Exp Clin Psychopharmacol. 2011;19:303-13.

264. Goldstein AL, Flett GL, Wekerle C. Child maltreatment, alcohol use and drinking consequences among male and female college students: an examination of drinking motives as mediators. Addict Behav. 2010;35:636-39.

265. Yeater EA, Austin JL, Green MJ, Smith JE. Coping mediates the relationship between posttraumatic stress disorder (PTSD) symptoms and alcohol use in homeless, ethnically diverse women: a preliminary study. Psychol Trauma: Theory, Res, Pract, Policy. 2010;2:307-10.

266. Gonzalez VM, Bradizza CM, Collins RL. Drinking to cope as a statistical mediator in the relationship between suicidal ideation and alcohol outcomes among underage college drinkers. Psychol Addictive Behav. 2009;23:443-51.

267. Young-Wolff KC, Kendler KS, Sintov ND, Prescott CA. Mood-related drinking motives mediate the familial association between major depression and alcohol dependence. Alcohol: Clin Exp Res. 2009;33:1476-86.

268. Mooney JL, Minor KI, Wells JB, Leukefeld C, Oser CB, Staton Tindall M. The relationship of stress, impulsivity, and beliefs to drug use severity in a sample of women prison inmates. Int J Offender Ther Comp Criminol. 2008;52:686-97.

269. Kaysen D, Dillworth TM, Simpson T, Waldrop A, Larimer ME, Resick PA. Domestic violence and alcohol use: trauma-related symptoms and motives for drinking. Addict Behav. 2007;32:1272-83.

270. Schuckit MA, Smith TL, Chacko Y. Evaluation of a depression-related model of alcohol problems in 430 probands from the San Diego prospective study. Drug Alcohol Depend. 2006;82:194-203. 
271. Ullman SE, Filipas HH, Townsend SM, Starzynski LL. Trauma exposure, posttraumatic stress disorder and problem drinking in sexual assault survivors. J Stud Alcohol. 2005;66:610-19.

272. Grayson CE, Nolen-Hoeksema S. Motives to drink as mediators between childhood sexual assault and alcohol problems in adult women. J Traum. Stress. 2005;18:137-45.

273. Reardon ML, Lang AR, Patrick CJ. An evaluation of relations among antisocial behavior, psychopathic traits, and alcohol problems in incarcerated men. Alcohol: Clin Exp Res. 2002;26:1188-97.

274. Stewart SH, Zvolensky MJ, Eifert GH. Negative-reinforcement drinking motives mediate the relation between anxiety sensitivity and increased drinking behavior. Pers Individ Differ. 2001;31:157-71.

275. Schuck AM, Widom CS. Childhood victimization and alcohol symptoms in females: causal inferences and hypothesized mediators. Child Abus Negl. 2001;25:1069-92.

276. Peirce RS, Frone MR, Russell M, Cooper ML. Relationship of financial strain and psychosocial resources to alcohol use and abuse: the mediating role of negative affect and drinking motives. J Health Soc Behav. 1994;35:291-308.

277. Schlagintweit HE, Thompson K, Goldstein AL, Stewart SH. An investigation of the association between shame and problem gambling: the mediating role of maladaptive coping motives. J Gambl Stud. 2017;33:1067-79.

278. Voon V, Derbyshire K, Rück C, Irvine MA, Worbe Y, Enander J, et al. Disorders of compulsivity: a common bias towards learning habits. Mol Psychiatry. 2015;20:345-52.

279. Sebold M, Nebe S, Garbusow M, Guggenmos M, Schad DJ, Beck A, et al. When habits are dangerous: alcohol expectancies and habitual decision making predict relapse in alcohol dependence. Biol Psychiatry. 2017;82:847-56.

280. Nebe S, Kroemer NB, Schad DJ, Bernhardt N, Sebold M, Müller DK, et al. No association of goal-directed and habitual control with alcohol consumption in young adults. Addict Biol. 2018;23:379-93.

281. Byrne KA, Otto AR, Pang B, Patrick CJ, Worthy DA. Substance use is associated with reduced devaluation sensitivity. Cogn Affect Behav Neurosci. 2019;19:40-55.

282. Gillan CM, Kosinski M, Whelan R, Phelps EA, Daw ND. Characterizing a psychiatric symptom dimension related to deficits in goal-directed control. eLife. 2016;5:e11305

283. Belin D, Mar AC, Dalley JW, Robbins TW, Everitt BJ. High impulsivity predicts the switch to compulsive cocaine-taking. Science. 2008;320:1352-55.

284. Jonkman S, Pelloux Y, Everitt BJ. Drug intake is sufficient, but conditioning is not necessary for the emergence of compulsive cocaine seeking after extended selfadministration. Neuropsychopharmacology. 2012;37:1612-9.

285. Datta U, Martini M, Fan M, Sun W. Compulsive sucrose- and cocaine-seeking behaviors in male and female Wistar rats. Psychopharmacology (Berlin). 2018;235:2395-405.

286. Datta U, Martini M, Sun W. Different functional domains measured by cocaine self-administration under the progressive-ratio and punishment schedules in male Wistar rats. Psychopharmacology (Berlin). 2018;235:897-907.

287. Pelloux $Y$, Everitt BJ, Dickinson A. Compulsive drug seeking by rats under punishment: effects of drug taking history. Psychopharmacology. 2007;194:127-37.

288. Belin D, Berson N, Balado E, Piazza PV, Deroche-Gamonet V. High-noveltypreference rats are predisposed to compulsive cocaine self-administration. Neuropsychopharmacology. 2010;36:569.

289. Bentzley BS, Jhou TC, Aston-Jones G. Economic demand predicts addiction-like behavior and therapeutic efficacy of oxytocin in the rat. Proc Natl Acad Sci USA. 2014;111:11822-27.
290. Pelloux Y, Murray JE, Everitt BJ. Differential vulnerability to the punishment of cocaine related behaviours: effects of locus of punishment, cocaine taking history and alternative reinforcer availability. Psychopharmacology. 2015:232:125-34.

291. James MH, Bowrey HE, Stopper CM, Aston-Jones G. Demand elasticity predicts addiction endophenotypes and the therapeutic efficacy of an orexin/hypocretin-1 receptor antagonist in rats. Eur J Neurosci. 2018;50:2602-12.

292. Deroche-Gamonet V, Belin D, Piazza PV. Evidence for addiction-like behavior in the rat. Science. 2004;305:1014-17.

293. Kasanetz F, Deroche-Gamonet V, Berson N, Balado E, Lafourcade M, Manzoni O, et al. Transition to addiction is associated with a persistent impairment in synaptic plasticity. Science. 2010;328:1709.

294. Vanderschuren LJMJ, Everitt BJ. Drug seeking becomes compulsive after prolonged cocaine self-administration. Science. 2004;305:1017-19.

295. Augier E, Barbier E, Dulman RS, Licheri V, Augier G, Domi E, et al. A molecular mechanism for choosing alcohol over an alternative reward. Science. 2018:360:1321-26.

296. Spanagel R. Animal models of addiction. Dialogues Clin Neurosci. 2017;19:247-58.

297. Muller CP, Schumann G. Drugs as instruments: a new framework for nonaddictive psychoactive drug use. Behav Brain Sci. 2011;34:293-310.

298. Hogarth L, Troisi JRI. A hierarchical instrumental decision theory of nicotine dependence. In: Balfour DJK, Munafò MR, editors. The neurobiology and genetics of nicotine and tobacco. Cham: Springer International Publishing; 2015. p. 165-91.

299. Mackillop J. The behavioral economics and neuroeconomics of alcohol use disorders. Alcohol: Clin Exp Res. 2016;40:672-85.

300. Berkman ET, Hutcherson CA, Livingston JL, Kahn LE, Inzlicht M. Self-control as value-based choice. Curr Dir Psychol Sci. 2017;26:422-28.

301. Shuai R, Bakou AE, Hardy L, Hogarth L. Ultra-brief breath counting (mindfulness) training promotes recovery from stress-induced alcohol-seeking in student drinkers. Addict Behav. 2020;102:106141.

302. Hogarth L, Hardy L, Bakou A, Mahlberg J, Weidemann G, Cashel S, et al. Negative mood induction increases choice of heroin versus food pictures in opiatedependent individuals: correlation with self-medication coping motives and subjective reactivity. Front Psychiatry. 2019;10:274.

303. Hogarth L. A critical review of habit theory of drug dependence. In: Verplanken $\mathrm{B}$, editor. The psychology of habit: theory, mechanisms, change, and contexts. Cham: Springer; 2018.

(i) Open Access This article is licensed under a Creative Common Attribution 4.0 International License, which permits use, sharing, adaptation, distribution and reproduction in any medium or format, as long as you give appropriate credit to the original author(s) and the source, provide a link to the Creative Commons license, and indicate if changes were made. The images or other third party material in this article are included in the article's Creative Commons license, unless indicated otherwise in a credit line to the material. If material is not included in the article's Creative Commons license and your intended use is not permitted by statutory regulation or exceeds the permitted use, you will need to obtain permission directly from the copyright holder. To view a copy of this license, visit http://creativecommons. org/licenses/by/4.0/.

(c) The Author(s) 2020 